Published in final edited form as:

J Org Chem. 2007 January 19; 72(2): 386-397.

\title{
Studies Toward the Asymmetric Synthesis of the Right Part of the Mycalamides
}

\author{
H. Marlon Zhong $\ddagger, \ddagger$, Jeong-Hun Sohn§, and Viresh H. Rawal§, \\ §Department of Chemistry, The University of Chicago 5735 South Ellis Avenue, Chicago, IL, 60637 \\ $\$$ Department of Chemistry, The Ohio State University, Columbus, OH, 43210
}

\begin{abstract}
Described herein is the asymmetric synthesis of a functionalized, trioxadecalin unit that comprises the right-hand part of the mycalamides and related natural products. The synthetic route involves a 16-step sequence that accomplishes the formation of two heterocyclic rings and the generation of five stereocenters. The synthesis commenced with a C2 symmetric starting material, diethyl Dtartrate, and took advantage of a relay of diastereoselective reactions to extend this four-carbon chain and introduce new chiral centers. Subsequent electrophile mediated cyclization afforded the desired pyran ring, which was then transformed into the desired, functionalized trioxadecalin skeleton.
\end{abstract}

\section{Introduction}

Mycalamides A-D, ${ }^{1,2}$ onnamides A-F, ${ }^{3}$ and theopederins A-L, ${ }^{4}$ are structurally related natural products isolated from marine sponge of the genera Mycale and Theonella, collected from New Zealand and Okinawan waters. These compounds all exhibit potent cytotoxicity-subnanomolar in many cases - against various tumor cell lines. Mycalamide A (1), in particular, has been evaluated as an anti-tumor agent based on its in vivo activity against P388 murine leukemia and a variety of solid tumor model systems, including Lewis lung, M5076, Burkitt's lymphoma, and MX-1 and CX-1 human tumor xenografts. ${ }^{5}$ Mycalamide A also displays significant anti-viral activity as well as immunosuppressive action against T-cell activation in mice. ${ }^{6}$ Interestingly, the structures of these sponge derived compounds are strikingly similar to that of pederin, a strong insect poison isolated from the terrestrial beetle, Paederus fuscipes. $^{7}$

These structurally challenging and potently bioactive compounds have stimulated considerable attention from the organic synthesis community. Kishi's pioneering total synthesis of mycalamide A and B was followed by reports from many other research groups, including Nakata, Roush, Kociensky, Trost, and Toyota on the total syntheses or formal syntheses of several members of this class. ${ }^{8-11}$ Studies towards the synthesis of analogs of these natural products 12 and SAR study of derivatives prepared from naturally occurring mycalamides have also been reported. ${ }^{13}$ The published synthetic studies were accomplished, for the most part, through a strategy that entailed the coupling of the left-half (3) portion with the right-half (4), often through an amide bond formation. The left half of mycalamide A is identical to the left half of pederin, and this portion is commonly referred to as pederic acid. Over the years, there has been extensive work on the synthesis of pederin, and this effort has resulted in several

\footnotetext{
*(773) 834-2194; fax-0805 vrawal@uchicago.edu.

*Present address: Johnson \& Johnson Pharmaceuticals Research and Development, L.L.C., Spring House, PA.

Asymmetric synthesis toward right half of mycalamide family
} 
solutions to the synthesis of the pederic acid unit. Consequently, in 1993, when we began our work in this area, we focused first on the synthesis of right part of the mycalamides, known as mycalamine (4). With six stereogenic centers decorating an array of nine contiguous carbons, mycalamine presents a formidable synthetic challenge. Our analysis revealed that the core of mycalamine could potentially be fashioned from the $\mathrm{C} 2$-symmetric chiral pool compound, tartaric acid. We report here the results of our efforts to transform diethyl tartrate into the tetrahydropyran-containing, trioxadecalin skeleton of mycalamine.

\section{Retrosynthetic Analysis}

When these studies were initiated, the only work on the synthesis of the mycalamides was the work of Hong and Kishi. ${ }^{8 a}, 10$ These authors had reported the successful coupling of pederic acid (3) with mycalamine (4) to yield mycalamide A (Scheme 1). In light of this accomplishment, our goal was to develop a strategy that would enable us to synthesize mycalamine more efficiently and by a route that controlled all newly created stereocenters.

The essence of our strategy to mycalamine is depicted in Scheme 2. The densely functionalized trioxadecalin framework (5), which also contains a labile aminal linkage, was expected to be derived from hydroxyaldehyde $\mathbf{6}$. Pyran $\mathbf{6}$ could, in turn, be formed from an acyclic precursor such as 7, through either electrophile or nucleophile promoted cyclization. Further analysis revealed that embedded in 7 was a four-carbon piece that was derivable from the $\mathrm{C} 2$-symmetric compound, tartaric acid, readily available in both antipodes. The required starting material, diethyl D-tartrate (10), would not only provide two of the stereocenters, C-11 and C-12, but also offer handles for the introduction of additional stereocenters. After transformation of $\mathbf{1 0}$ into a properly protected aldehyde (8), the third stereocenter (C-13), as well as the geminal dimethyl groups could be introduced by a chelation controlled addition of tributylprenylstannane (9).

\section{RESULTS AND DISCUSSION}

\section{Tartrate Desymmetrization and Diastereoselective Prenylstannane Addition}

Central to the strategy to mycalamine was the use of a tartrate-derived four carbon piece, to which would be grafted the additional carbons through diastereoselective reactions. In preparation for this, the hydroxyl groups of diethyl D-tartrate needed to be protected. The methoxy methyl ether (MOM) protecting group was selected over a silyl group since it was expected to be stable to the basic conditions present in the next few steps, yet removable under mild condition when necessary and compatible with the required chelation controlled addition of the prenyl unit. Importantly, the hope was to parlay the methylene of the MOM group into the $-\mathrm{CH}_{2}-$ of the C-ring acetal. Treatment of tartrate $\mathbf{1 0}$ with $\mathrm{P}_{2} \mathrm{O}_{5}$ in dimethoxymethane and dichloromethane afforded the bis-MOM protected tartrate in quantitative yield (Scheme 3). 14 Attempted reduction of the bis-MOM ester with DIBAL-H to yield a mono-aldehyde directly proved unsatisfactory due to competing over reduction of the aldehyde as well as reduction of the second ester. Consequently, the bis-MOM ester was reduced down to diol $\mathbf{1 1}^{15 \mathrm{a}}$ using an excess amount of $\mathrm{LiAlH}_{4}$. The high water solubility of diol $\mathbf{1 1}$ made it difficult to isolate by standard extraction. Good results were obtained, however, when the reaction was quenched with a minimum amount of water, and the gelatinous, crude reaction product was subjected to Soxhlet extraction with THF for $48 \mathrm{~h}$. Alternatively, the diol was isolated in good yield upon quenching the reaction by successive addition of water ( $1 \mathrm{~mL} / 1 \mathrm{~g}$ of $\mathrm{LAH}), 15 \%$ $\mathrm{NaOH}(1 \mathrm{~mL} / 1 \mathrm{~g}$ of $\mathrm{LAH})$, and water $(3 \mathrm{~mL} / 1 \mathrm{~g}$ of $\mathrm{LAH})$, followed by filtration. $15 \mathrm{~b}$, The two hydroxyls in $\mathbf{1 1}$ are chemically equivalent because of $\mathrm{C} 2$ symmetry so protection of one renders the molecule unsymmetrical. The desymmetrization was accomplished in quantitative yield by treating $\mathbf{1 1}$ with 1.2 equivalents of $n$-BuLi and 1 equivalent of $t$-butyldiphenylsilyl chloride 
(TBDPSCl) in THF solution. Swern oxidation of the free alcohol gave the desired aldehyde (12), which was poised for a key C-C bond-forming step, the addition of tributylprenylstannane.

The plan for the introduction of the gem-dimethyl group entailed reaction of stannane 9 with aldehyde 12 in the presence of a suitable Lewis acid. ${ }^{11 \mathrm{~d}, 16}$ Diastereoselective addition was expected based on the chelation-Cram model (Figure 2), wherein the prenyl unit would add to the less hindered face of the conformationally locked carbonyl. Several conditions were examined for this addition reaction, and the results are summarized in Table 1. The addition product 13 was obtained with high diastereoselectivity (14:1), but in modest and variable yields (up to $65 \%$ ) with $\mathrm{TiCl}_{4}$ as the Lewis acid at $-78{ }^{\circ} \mathrm{C}$. Decomposition products usually accompanied the desired product. In one instance, the major side-product was the expected addition product in which the MOM group on the adjacent alcohol had been removed. Although not sought at the time, this regioselectively-deprotected diol could prove quite useful in an improved synthesis of the trioxadecalin skeleton. A messy reaction was observed with $\mathrm{BF}_{3} \cdot \mathrm{Et}_{2} \mathrm{O}$ as the Lewis acid. The best results were obtained using the weak Lewis acid, $\mathrm{ZnBr}_{2}$. The reaction rate and diastereoselectivity were found to vary significantly with temperature. Whereas a very slow reaction took place at $-78{ }^{\circ} \mathrm{C}$, it progressed quickly at room temperature $(8 \mathrm{~h}, 77 \%)$, albeit with poor diastereoselectivity $(2: 1)$. The reaction proceeded well at $-10{ }^{\circ} \mathrm{C}$ and afforded alcohol $\mathbf{1 3}$ in $81 \%$ yield and with $>12: 1$ diastereoselectivity. The conditions were fine-tuned, such that the major product was obtained in $90 \%$ yield with essentially none of the minor diastereomer.

In order to determine the stereochemistry of the newly formed chiral center, alcohol $\mathbf{1 3}$ was converted into a cyclic form, such that NOE analysis would reveal the relative position of different substituents (Scheme 4). Removal of the TBDPS group with TBAF followed by treatment of the resulting diol with NMO/TPAP combination provided a lactone in $61 \%$ yield. ${ }^{17}$ Unfortunately, the relative stereochemistry of the substituents in the lactone could not be determined, since the critical signals in its ${ }^{1} \mathrm{H}$ NMR spectrum were not cleanly separated. The same problem was encountered with diol 14, obtained upon the removal of both MOM groups with $\mathrm{BBr}_{3} \cdot \mathrm{Me}_{2} \mathrm{~S} .{ }^{18} \mathrm{~A}$ suitable NOE sample was finally obtained by converting diol $\mathbf{1 4}$ into a monomethoxy derivative. Treatment of $\mathbf{1 4}$ with $\mathrm{Ag}_{2} \mathrm{O}$ and $\mathrm{MeI}$ in $\mathrm{CH}_{2} \mathrm{Cl}_{2}$ gave, in low yield, a 1:1 mixture of the mono- and dimethylated products. The yield of this reaction was not optimized since enough material was obtained for the purpose of NMR analysis. All protons in the NMR spectrum of $\mathbf{1 6}$ were nicely separated, and NOE analysis indicated that the stereochemistry of the newly formed center was as shown ( $S$ configuration), as expected for chelation controlled addition of the prenylstannane.

A chemical transformation corroborated the above assigned stereochemistry. Lactone-alcohol $\mathbf{1 6}$ readily underwent a facile selenoetherification reaction to afford bicyclic compound $\mathbf{1 7}$ in quantitative yield, as a 1:1 mixture of diastereomers (Scheme 5). ${ }^{19}$ If the prenyl unit were oriented trans to the free hydroxyl, then the cyclization would be expected to proceed with difficulty, if at all, as it would produce the strained trans-[5,5]bicyclic lactone. These results confirmed that $\mathrm{ZnBr}_{2}$ promoted addition of tributylprenylstannane (9) onto aldehyde $\mathbf{1 2}$ was chelation controlled and that it introduced the desired stereochemistry at the C-13 carbon center.

\section{Formation of Tetrahydropyran Ring by Electrophilic Cyclization}

After the stereoselective installation of the prenyl group, the next objective en route to mycalamine was formation of the tetrahydropyran ring through an electrophile-mediated cyclization reaction. An important requirement for this process was that the cyclization produce the tetrahydropyran ring with the 2 and 6 position substituents in a trans arrangement. In preparation for the cyclization, the hydroxyl group of $\mathbf{1 3}$ was converted into a methyl ether (18), as required for the natural product (Scheme 6). Treatment of $\mathbf{1 3}$ with $\mathrm{NaH}$ and $\mathrm{MeI}$ in 
THF at room temperature gave the methyl ether in excellent yield (>90\%). Although there was no precedent for the direct electrophilic cyclization of MOM-protected alcohols (e.g., 18) onto an alkene, it was investigated as it represented the most concise route to the desired pyran. ${ }^{20}$ When MOM ether 18 was treated with either N-phenylselenophthalimide (NPSP) or Nbromosuccinimide (NBS), a facile cyclization took place. Whereas the reaction with NPSP was unselective, the reaction with NBS proceeded with high diastereoselectivity. From the NMR spectra of the products, however, it was not clear if the cyclizations had given the fiveor six-membered ring products.

Since it was not possible to unambiguously distinguish between the different products in the above reaction, several derivatives of the cyclization products were prepared for NMR study as well as X-ray crystallographic analysis. Ultimately, successful structural assignment was possible with diol $\mathbf{2 1}$ (or, potentially, 22), which was obtained by deprotection of bromide 20 (or 20a). All the protons in $\mathbf{2 1}$ were sufficiently separated so as to allow a detailed protonproton decoupling study. Proton a, which appeared most downfield among such protons, was coupled to proton $\mathbf{b}$, the only one in the group that can give a unique doublet. This coupling pattern can only occur in the five-membered ring compound 21. Indeed, no coupling would be expected between protons $\mathbf{a}$ and $\mathbf{b}$ in the six-membered ring compound $\mathbf{2 2}$. The five-membered ring product was also produced upon electrophilic cyclization of $\mathbf{1 8}^{\prime}$ (vide infra) the free diol that results from removal of the two MOM groups of $\mathbf{1 8 .}$

Based on the above results, it was clear that we would need to manipulate the protecting groups on the oxygens to differentiate them and thereby overcome the kinetic preference for fivemembered ring formation. The two MOM groups of $\mathbf{1 8}$ were removed in refluxing $i-\mathrm{PrOH}$ with a catalytic amount of PPTS to give the corresponding diol (18') in $80 \%$ yield (Scheme 7). 21 Treatment of diol $\mathbf{1 8}^{\prime}$ with 1.2 equivalents of TMSCl and an excess amount of triethylamine in $\mathrm{CH}_{2} \mathrm{Cl}_{2}$ promoted the selective, but slow, formation of the monoprotected silyl ether 23 . The reaction proceeded well with 2 equivalents of TMSCl and yielded only the mono-silyl product in $93 \%$ yield. This result illustrates the significant differences that exist in the chemical and steric environments of these two hydroxyl groups. In order to prevent the formation of five-membered compound by electrophilic cyclization, the free alcohol was protected with the MOM group using NaH followed by MOMCl. Subsequent removal of the TMS and TBDPS groups using TBAF gave diol 24 in 53\% overall yield.

Surprisingly, the electrophilic cyclization of $\mathbf{2 4}$ with NBS again gave the five-membered diol 21 as the sole product (Scheme 7). These results highlight in an emphatic way the strong kinetic preference for the formation of the five-membered ring product. Despite the presence of a free hydroxyl group available for the formation of the six-membered ring, the MOM protected hydroxyl participated instead and produced the kinetically preferred five-membered ring product.

It was clear from the above results that the $\mathrm{C}-12$ hydroxyl had to be blocked by a more effective protecting group. The benzoyl group was chosen as it was expected to resist the electrophilic cyclization conditions and, more importantly, to reduce the nucleophilic capability of the C-12 oxygen. Introduction of this group on $\mathbf{2 3}$ was found to be difficult under conventional conditions due to the greater steric hindrance of the $\mathrm{C}-12$ hydroxyl group. Under forcing conditions, the major product resulted from a desilylative benzoylation of the $\mathrm{C}-11$ alcohol. The desired benzoyl product (25) was eventually obtained in excellent yield when the reaction was carried out using pyridine as the solvent for the reaction. Selective removal of the TMS group using PPTS in MeOH gave alcohol 26, which was expected to give only the sixmembered ring product. Indeed, upon treatment of alcohol 26 with NBS, a smooth cyclization took place to form desired tetrahydropyran derivative $\mathbf{2 7}$ in $\mathbf{7 7 \%}$ yield, as a single diastereomer (Scheme 8). 
With the six-membered product in hand, the next issue was determination of the stereochemistry at the newly formed chiral center. The relative stereochemistry in pyran $\mathbf{2 7}$ could not be established unambiguously even after extensive NMR studies. Since a definitive answer was available by X-ray crystallographic analysis, several derivatives of $\mathbf{2 7}$ were prepared with the hope of getting one that was nicely crystalline. A suitable crystal was finally obtained from alcohol 28, prepared by treatment of $\mathbf{2 7}$ with concentrated $\mathrm{HCl}$ in $\mathrm{MeOH}$ (Scheme 9). Unfortunately, the result of X-ray analysis ${ }^{22 a}$ of $\mathbf{2 8}$ indicated that the newly formed chiral center had the $R$ configuration, epimeric to that found in the natural products. In other words, rather than the desired 2,6-trans-pyran, the product obtained was the 2,6-cispyran. This outcome was puzzling since our analysis of the problem, as well as literature precedent with simpler systems, ${ }^{22 \mathrm{~b}}$ had suggested that the major product would be the desired trans-pyran, 28a.

Two different avenues were investigated in order to address the diastereoselectivity issue. One approach was to improve the desired diastereoselectivity by varying the reagents and the reaction conditions. The other was to control the available conformations for the transition state in the electrophilic cyclization by chemically modifying and restricting the flexibility of the cyclization precursors. To evaluate the first tactic, the cyclization of precursor $\mathbf{2 6}$ was carried out using a wide variety of reagents and conditions. Some of these results are summarized in Table $2.20 \mathrm{~b}, 22$

As can be seen from the results, NBS in DMF promoted the most selective cyclization, albeit to produce the undesired pyran derivative. Most of the other electrophiles afforded modest selectivity, producing more-or-less equal amounts of the two diastereomeric products. The reaction temperature did not affect diastereoselectivity significantly. The most promising result was with N-phenylselenophthalimide (NPSP), which gave the two diastereomers in approximately 1:1 ratio in DMF. A study of solvent effects showed that the desired product predominated in less polar solvents. Under the best conditions found, using a combination of NPSP and CSA in $\mathrm{CH}_{2} \mathrm{Cl}_{2}$, the cyclization proceeded to afford the desired diastereomer in a $1.8 / 1$ ratio.

The structures of the two cyclization products were assigned by correlation to $\mathbf{2 8}$, whose structure was established through X-ray crystallography. The diastereomeric mixture of the NPSP cyclization products $(X=\mathrm{PhSe}, 29 \mathrm{a}$ and 29b) was separable by flash column chromatography. Treatment of 29a with concentrated $\mathrm{HCl}$ in $\mathrm{MeOH}$ gave alcohol 30, whose NMR spectrum had all oxygen-substituted protons nicely separated. NOE experiments convincingly showed that the cyclization had taken place to position the selenomethyl unit trans to the benzoyl group. A chemical correlation provided further support to the assigned structures. Reduction of $\mathbf{2 9 b}$, the minor diastereomer from NPSP cyclization, with $\mathrm{Bu}_{3} \mathrm{SnH}$ gave pyran $31,{ }^{23}$ identical to the product obtained from the reduction of bromide $\mathbf{2 7}$. The relative stereochemistry of the latter had been established by X-ray crystallographic analysis, as described earlier (Scheme 10).

The differing stereochemical outcome of the NBS and NPSP mediated cyclizations is difficult to understand. The reaction outcome is expected to depend on the kinetic selectivity for the cyclic onium ion formation as well as equilibration between two possible onium ions (32a/ 32b) prior to cyclization. ${ }^{22 b}$ In the case of NBS cyclization, formation of the three-centered bromonium species is generally believed to be freely reversible, ${ }^{24}$ so the observed diastereoselectivity may reflect the greater thermodynamic stability of the cyclized intermediate, tetrahydropyranonium ion $\mathbf{3 3 b}$. In other words, reversible formation of the two bromonium ions is followed by ring closure to give the more stable final product, $\mathbf{3 4 b}$. In the case of NPSP cyclization, the three-centered selenonium intermediate from the first step is expected to be relatively stable. The stereochemistry of the product is determined upon 
coordination of the olefin with the electrophile, which is then followed by the stereospecific ring closure step. The low diastereoselectivity for the NPSP mediated cyclization reflects the modest kinetic selectivity expected for complexation of the electrophilic selenium species to the diastereomeric faces of the alkene (Scheme 11).

\section{Control of Cyclization Diastereoselectivity}

In addition to the investigation of reagents and the reaction conditions, numerous other means were explored to improve the cyclization diastereoselectivity, such as modification of the cyclization precursor. The general idea was to introduce an additional ring, the conformation of which would bias the conformation of the transition state leading to the key cyclization.

A promising modification involved the introduction of an acetonide ring from alcohol $\mathbf{1 3 .}$ Based on conformational analysis of the expected transition state, depicted without the electrophile in Figure 4, the acetonide ring was expected to lock the system and allow cyclization by only one of the two possible transition states. Transition state 35a would lead to the desired diastereomer, as it is expected to be of lower energy than $\mathbf{3 5 b}$, which should experience more 1,3-diaxial interactions during the ring closure.

The required "locked" precursors were prepared from alcohol 13, the prenylstannane addition product. ${ }^{25}$ Upon treatment of $\mathbf{1 3}$ with $p$-TsOH in acetone, the alcohol was converted to acetonide 36 in good yield (Scheme 12). When the reaction was carried out under more vigorous conditions, the second MOM group was also removed, giving alcohol $\mathbf{3 7}$ as the major product. Numerous reagents and reaction conditions were examined for carrying out the electrophilic cyclization of $\mathbf{3 6}$ and $\mathbf{3 7}$, but to no avail. In no case were cyclized products obtained. The only time an isolable, electrophile addition product was obtained was when $\mathbf{3 7}$ was treated with NBS and propylene oxide in DMF for $24 \mathrm{~h}$ at room temperature. These conditions produced in $67 \%$ yield a formate-containing product (tentatively assigned as $\mathbf{3 8}$ ), presumably by addition of DMF to the expected bromonium ion followed by hydrolysis. These results show that the cyclization product, a trans-fused 5,6-bicyclic system, is evidently too strained to be formed under the reaction conditions used.

The cis-decalin structure present in the right part of mycalamides suggested an alternative synthetic design for closure of the pyran unit. The idea was to start with a six-membered acetonide from which to construct the second ring of the decalin. Assuming that the natural product represented the thermodynamically more stable diastereomer, then the expectation was that the cyclization step would favor formation of the desired trans-2,6-substituted pyran ring. The cyclization precursor for this approach was prepared in three steps from one of the earlier intermediates, 25, as outlined in Scheme 13. One-step deprotection of both silyl groups in 25, carried out in 5\% methanolic $\mathrm{HCl}$ solution, gave the expected diol, 39, along with diol 40, in which the benzoyl group had migrated to a less congested location. Without optimization, the benzoyl migration product (40) was converted into an acetonide ketal (41), which upon basic hydrolysis gave alcohol $\mathbf{4 2}$ in high overall yield. Alcohol $\mathbf{4 2}$ was subjected to electrophilic cyclization conditions using NBS and gave the expected dioxa-decalin product 43 in $55 \%$ yield, favoring the undesired diastereomer by 1.9/1. If one assumes that the steric interactions in the products resemble those present in the transition states, then the observed diastereoselectivity may arise from the presence of more serious 1,3-diaxial interactions in the minor (desired) product, shown in brackets, as compared to the major one.

\section{Trioxadecalin Ring Formation: A Functionalized B,C-Ring Skeleton}

Given the difficulties encountered in trying to promote an electrophilic cyclization favoring the desired diastereomer, a decision was made to continue the synthetic sequence using the major diastereomer of the selenoetherification (29a) and work out the remaining steps to 
generate the trioxadecalin skeleton of mycalamine. Deprotection of both the benzoyl and the TBDPS groups was achieved in one step by treatment of 29a with $2 \mathrm{~N} \mathrm{NaOH}$ in $\mathrm{MeOH}$ at 60 ${ }^{\circ} \mathrm{C}$, which afforded diol $\mathbf{4 4}$ in $94 \%$ yield. Formation of a simple dioxane ring $\mathrm{C}$ was examined at this point using the methodology developed by Gras and his colleagues. ${ }^{26}$ A solution of diol 44 in dimethoxymethane was treated with a catalytic amount of $\mathrm{LiBr}$ and $p$-TsOH under reflux condition for $10 \mathrm{~h}$ to furnish the trioxadecalin system (45) in $81 \%$ yield (Scheme 14).

While technically a trioxadecalin skeleton, compound $\mathbf{4 5}$ lacks a functional group at the C-10 position, necessary for further transformation to an aminal, as required in the natural product. A precursor with the C-10 carbon at the aldehyde oxidation state would be ideal, as it would allow for introduction of both the acetal and the aminal functionalities. Thus, it was necessary to selectively oxidize the primary hydroxyl group of $\mathbf{4 4}$ (or a related compound) into an aldehyde without oxidation of the secondary hydroxyl group. This is a problem for which there are no good solutions. The few methods available for such selective oxidations ${ }^{27}$ are further hampered in the case at hand by the presence of the easily oxidizable selenophenyl group. ${ }^{28}$ Several different protocols were examined for the selective oxidation of the primary hydroxyl group in $\mathbf{4 4}$ and related compounds, but none were successful. The oxidation of benzoyl alcohol 30 was also examined, but the expected product (46) was unstable and led to what was tentatively assigned as the $\beta$-elimination product $\mathbf{4 7}$ (Scheme 15). ${ }^{29}$

Curiously, in contrast to the difficulties encountered above, selective oxidation of the primary alcohol over the secondary alcohol was possible for the undesired diol diastereomer obtained through NBS cyclization (Scheme 16). The benzoyl and TBDPS groups in $\mathbf{2 7}$ were removed in high yield through a one-pot procedure. The resulting diol (48), when subjected to standard Swern oxidation conditions, produced what was considered to be the desired hydroxyaldehyde 49. The NMR spectrum of compound 49, however, lacked the telltale aldehydes peak in 9-10 ppm region, and indicated that it existed as either the hydrate or, possibly, the dimer. Indeed, treatment of the oxidation product with a catalytic amount of $p$ - $\mathrm{TsOH}$ in $\mathrm{MeOH}$ transformed it to the corresponding dimethoxy acetal (50), which was isolated in $72 \%$ yield. It should be noted that the selective oxidation of a secondary alcohol over a primary one is well precedented, especially with chromium oxidants. Thus, treatment of diol 48 with $\mathrm{PDC}$ in $\mathrm{CH}_{2} \mathrm{Cl}_{2}$ for $24 \mathrm{~h}$ at room temperature provided ketone $\mathbf{5 1}$ in $82 \%$ yield.

After successfully exploring various oxidants on the undesired pyran diastereomer, we directed our efforts to the selective oxidation and further elaboration of the desired diastereomer of the selenocyclization product, 29a (Scheme 17). Treatment of 29a with TBAF in THF gave not the expected primary alcohol, but secondary alcohol $\mathbf{5 2}(84 \%)$, which arises from a 1,2migration of the benzoyl group. ${ }^{30}$ In all likelihood, this migration takes place intramolecularly, although this notion was not verified using crossover studies. This was one of several instances in which groups migrated away from the sterically demanding gem-dimethyl groups. The secondary hydroxyl group of $\mathbf{5 2}$ was protected as a MOM ether (53), and the benzoyl group was removed by saponification to give free alcohol $\mathbf{5 4}$ in nearly quantitative yield. The primary hydroxyl group was then oxidized under Swern conditions to afford aldehyde 55. Finally, upon treatment of MOM-aldehyde $\mathbf{5 5}$ with paraformaldehyde and concentrated $\mathrm{HCl}$, it was transformed into the desired trioxadecalin unit $(\mathbf{5 6})$, isolated in $92 \%$ yield. ${ }^{8 \mathrm{a}}$ The diastereomeric ratio of $\mathbf{5 6}$ was initially $2: 1$ and slowly became $1: 1$ upon standing in $\mathrm{CDCl}_{3}$, an acidic environment. The transformation of the lactol hydroxyl into an amino group, which is necessary for coupling to the pederic acid part, has been already been demonstrated in an analogous compound in Kishi's mycalamide synthesis. $8 \mathrm{a}, 8 \mathrm{~b}, 10$ The selenophenyl group obtained through the above sequence is expected to be useful for the introduction of various side chains necessary for the mycalamides and related compounds. 


\section{CONCLUSION}

We have described the asymmetric synthesis of trioxadecalin unit 56, an important intermediate for the synthesis of mycalamides and related natural compounds. The overall synthetic sequence, which required the formation of two heterocycles and the generation of five stereocenters, was executed in 16 steps in $12 \%$ overall yield from the $\mathrm{C} 2$ symmetric starting material, diethyl D-tartrate (Scheme 18). The strategy took advantage of diastereoselective reactions to extend the four-carbon chain of tartrate. Subsequent electrophile mediated cyclization afforded the desired 2,6-trans substituted pyran, which was then transformed into a functionalized trioxadecalin skeleton. ${ }^{31}$

\section{EXPERIMENTAL SECTION}

\section{(4S,5R,6R)-5,6-Bis(methoxymethoxy)-3,3-dimethyl-7-[(1,1-dimethylethyl)diphenylsilyl] oxy-4-hydroxy-1-heptene (13)}

To a solution of aldehyde $12(8.014 \mathrm{~g}, 17.94 \mathrm{mmol})$ and tri $(n$-butyl)prenyl stannane $(6.63 \mathrm{~mL}$, $19.73 \mathrm{mmol})$ in $\mathrm{CH}_{2} \mathrm{Cl}_{2}(30 \mathrm{~mL})$ was added $\mathrm{ZnBr}_{2}(8.890 \mathrm{~g}, 39.48 \mathrm{mmol})$ at $-78^{\circ} \mathrm{C}$. The resulting mixture was allowed to warm to $0{ }^{\circ} \mathrm{C}$ over $6 \mathrm{~h}$, and stir further for $2 \mathrm{~h}$ at $0{ }^{\circ} \mathrm{C}$. The reaction was quenched with saturated $\mathrm{NaHCO}_{3}$ solution $(80 \mathrm{~mL})$ and brine $(80 \mathrm{~mL})$. The aqueous layer was separated and extracted with $\mathrm{CH}_{2} \mathrm{Cl}_{2}(3 \times 100 \mathrm{~mL})$. The combined organic phase was washed with saturated $\mathrm{NaHCO}_{3}$ solution $(70 \mathrm{~mL})$ and dried over $\mathrm{MgSO}_{4}$. The solvent was removed under reduced pressure and the crude yellow oil was purified by flash column chromatography (EtOAc/hexane, 1:6) to afford hydroxyl alkene $\mathbf{1 3}(8.345 \mathrm{~g}, 90 \%$, $d r>50: 1)$ as a colorless oil: $[\alpha]^{23} \mathrm{D}-20.8^{\circ}\left(c 1.15, \mathrm{CHCl}_{3}\right) ;{ }^{1} \mathrm{H} \mathrm{NMR}\left(500 \mathrm{MHz}, \mathrm{CDCl}_{3}\right) \delta$ $7.66(\mathrm{~m}, 4 \mathrm{H}), 7.42-7.33(\mathrm{~m}, 6 \mathrm{H}), 5.88(\mathrm{dd}, J=10.5,17.9 \mathrm{~Hz}, 1 \mathrm{H}), 5.01(\mathrm{~m}, 1 \mathrm{H}), 4.98(\mathrm{dd}, J=$ $1.1,4.3 \mathrm{~Hz}, 1 \mathrm{H}), 4.79(\mathrm{~d}, J=6.7 \mathrm{~Hz}, 1 \mathrm{H}), 4.65(\mathrm{~d}, J=6.7 \mathrm{~Hz}, 1 \mathrm{H}), 4.62(\mathrm{dd}, J=6.6,10.4 \mathrm{~Hz}$, $2 \mathrm{H}), 3.91(\mathrm{dd}, J=8.0,11.9 \mathrm{~Hz}, 1 \mathrm{H}), 3.84(\mathrm{~m}, 2 \mathrm{H}), 3.75(\mathrm{dd}, J=1.7,3.9 \mathrm{~Hz}, 1 \mathrm{H}), 3.50(\mathrm{dd}, J=$ $1.7,8.0 \mathrm{~Hz}, 1 \mathrm{H}), 3.35(\mathrm{~s}, 3 \mathrm{H}), 3.26(\mathrm{~s}, 3 \mathrm{H}), 2.59(\mathrm{~d}, J=8.0 \mathrm{~Hz}, 1 \mathrm{H}), 1.05(\mathrm{~s}, 9 \mathrm{H}), 1.03(\mathrm{~s}$, $6 \mathrm{H}) ;{ }^{13} \mathrm{C}$ NMR $\left(125 \mathrm{MHz}, \mathrm{CDCl}_{3}\right) \delta 145.0,135.6,135.5,133.4,133.3,129.65,129.62,127.63$, $127.61,112.3,97.9,97.0,79.2,75.5,74.7,63.8,56.4,55.8,41.5,26.8,24.4,22.2,19.1$; IR (neat) $3558,1111,1034 \mathrm{~cm}^{-1}$; HRMS m/e calc'd for $\mathrm{C} \mathrm{Zn}_{26} \mathrm{H}_{35} \mathrm{O}_{3} \mathrm{Si}\left(\mathrm{M}^{+}-\mathrm{C}_{2} \mathrm{H}_{2} \mathrm{O}_{2}\right) 423.2355$, found 423.2336 .

\section{(3S,4R,5S)-3,4-dihydroxy-5-(1,1-dimethyl-2-propenyl)-2H-tetrahydro furan-2-one (14)}

A solution of hydroxy alkene $\mathbf{1 3}(1.034 \mathrm{~g}, 2.001 \mathrm{mmol})$ in THF $(10 \mathrm{~mL})$ was treated with TBAF (1.0 M in THF, $4.00 \mathrm{~mL}, 4.00 \mathrm{mmol}$ ), and the reaction mixture was stirred for $2 \mathrm{~h}$ at room temperature. The reaction was quenched with $\mathrm{H}_{2} \mathrm{O}(20 \mathrm{~mL})$ and extracted with ether $(4 \times 20$ $\mathrm{mL})$. The combined extract was washed with brine $(30 \mathrm{~mL})$ and dried over anhydrous $\mathrm{Na}_{2} \mathrm{SO}_{4}$ The solvent was removed under reduced pressure, and the crude oil was purified by flash column chromatography (EtOAc/hexane, $1: 1)$ to afford the expected diol $(0.557 \mathrm{~g}, 100 \%)$ as a colorless oil: ${ }^{1} \mathrm{H}$ NMR $\left(300 \mathrm{MHz}, \mathrm{CDCl}_{3}\right) \delta 5.87(\mathrm{dd}, J=18.0,10.3 \mathrm{~Hz}, 1 \mathrm{H}), 5.06(\mathrm{br} \mathrm{s}$, $1 \mathrm{H}), 5.01(\mathrm{dd}, J=5.7,1.4 \mathrm{~Hz}, 1 \mathrm{H}), 4.713(\mathrm{~m}, 4 \mathrm{H}), 3.80(\mathrm{~m}, 4 \mathrm{H}), 3.61(\mathrm{~d}, J=9.2 \mathrm{~Hz}, 1 \mathrm{H}), 3.43$ (s, 3H), $3.40(\mathrm{~s}, 3 \mathrm{H}), 2.75$ (d, $J=9.4 \mathrm{~Hz}, 1 \mathrm{H}), 1.06(\mathrm{~s}, 9 \mathrm{H}), 1.05(\mathrm{~s}, 6 \mathrm{H}) ;{ }^{13} \mathrm{C}$ NMR $(63 \mathrm{MHz}$, $\left.\mathrm{CDCl}_{3}\right) \delta 144.6,112.4,98.1,96.5,79.6,76.0,74.2,61.0,56.4,55.7,41.4,24.5,22.5$; IR (neat) $3447,1030 \mathrm{~cm}^{-1}$; HRMS m/e calc'd for $\mathrm{C}_{10} \mathrm{H}_{18} \mathrm{O}_{3}\left(\mathrm{M}^{+}-\mathrm{C}_{3} \mathrm{H}_{8} \mathrm{O}_{3}\right)$ 186.1256, found 186.1240 . To a stirred mixture of above diol (278 mg, $0.999 \mathrm{mmol})$, NMO (352 mg, $3.00 \mathrm{mmol})$ and activated molecular sieves $(0.5 \mathrm{~g})$ in $\mathrm{CH}_{2} \mathrm{Cl}_{2}(10 \mathrm{~mL})$ was added a catalytic amount of TPAP ( $8.0 \mathrm{mg}, 0.023 \mathrm{mmol}$ ) in one portion at room temperature. The resulting deep blue solution was stirred at room temperature for $18 \mathrm{~h}$. Upon consumption of the starting material, the reaction mixture was filtered through a pad of silica gel, which was then washed with $\mathrm{CH}_{2} \mathrm{Cl}_{2}$. The filtrate was concentrated in vacua and the crude oil was purified by flash column chromatography (EtOAc/hexane, $1: 5)$ to afford bis-MOM lactone $(176 \mathrm{mg}, 61 \%)$ as a colorless 
oil: ${ }^{1} \mathrm{H}$ NMR $\left(250 \mathrm{MHz}, \mathrm{CDCl}_{3}\right) \delta 6.02(\mathrm{dd}, J=17.6,10.1 \mathrm{~Hz}, 1 \mathrm{H}), 5.11(\mathrm{dd}, J=17.6,1.2 \mathrm{~Hz}$, $1 \mathrm{H}), 5.06(\mathrm{dd}, J=10.1,1.2 \mathrm{~Hz}, 1 \mathrm{H}), 4.97(\mathrm{~d}, J=6.7 \mathrm{~Hz}, 1 \mathrm{H}), 4.68(\mathrm{~m}, 3 \mathrm{H}), 4.36(\mathrm{~s}, 3 \mathrm{H}), 3.43$ (s, 3H), $3.41(\mathrm{~s}, 3 \mathrm{H}), 1.21(\mathrm{~s}, 3 \mathrm{H}), 1.20(\mathrm{~s}, 3 \mathrm{H}) ;{ }^{13} \mathrm{C} \mathrm{NMR}\left(63 \mathrm{MHz}, \mathrm{CDCl}_{3}\right) \delta$ 172.7, 143.1, 113.3, 96.4, 95.6, 86.6, 78.7, 74.8, 56.3, 55.9, 39.5, 24.6, 23.4; IR (neat) 1787, 1153, 1108 $\mathrm{cm}^{-1}$; HRMS m/e calc'd for $\mathrm{C}_{13} \mathrm{H}_{22} \mathrm{O}_{6}\left(\mathrm{M}^{+}\right)$274.1416, found 274.1416. A stirred solution of the above bis-MOM lactone $(235 \mathrm{mg}, 0.816 \mathrm{mmol})$ in $\mathrm{CH}_{2} \mathrm{Cl}_{2}(8 \mathrm{~mL})$ was treated with solid $\mathrm{BBr}_{3} \cdot \mathrm{Me}_{2} \mathrm{~S}(469 \mathrm{mg}, 1.50 \mathrm{mmol})$ in one portion at $0{ }^{\circ} \mathrm{C}$, and the mixture was stirred at room temperature for $2 \mathrm{~h}$. The reaction was quenched with saturated $\mathrm{NaHCO}_{3}$ solution $(20 \mathrm{~mL})$ and extracted with $\mathrm{Et}_{2}(3 \times 15 \mathrm{~mL})$. The combined $\mathrm{Et}_{2} \mathrm{O}$ phase was washed with brine $(30 \mathrm{~mL})$ and dried over anhydrous $\mathrm{Na}_{2} \mathrm{SO}_{4}$. After removal of the solvent under reduced pressure, the crude oil was purified by flash column chromatography (EtOAc/hexane, 1:2) to afford dihydroxy lactone $14(102 \mathrm{mg}, 69 \%)$ as a colorless oil: ${ }^{1} \mathrm{H}$ NMR $\left(300 \mathrm{MHz}, \mathrm{CDCl}_{3}\right) \delta 6.11(\mathrm{dd}, J=17.7$, $10.9 \mathrm{~Hz}, 1 \mathrm{H}), 5.18$ (dd, $J=17.7,1.0 \mathrm{~Hz}, 1 \mathrm{H}), 5.15(\mathrm{dd}, J=10.9,1.0 \mathrm{~Hz}, 1 \mathrm{H}), 4.52(\mathrm{~m}, 1 \mathrm{H})$, $4.38(\mathrm{~m}, 2 \mathrm{H}), 4.29$ (br s, 1H), 3.28 (br s, 1H), 1.24 (s, 3H), 1.20 (s, 3H); ${ }^{13} \mathrm{C}$ NMR (63 MHz, $\left.\mathrm{CDCl}_{3}\right) \delta$ 175.8, 143.0, 114.5, 87.1, 75.2, 73.8, 39.8, 24.7, 23.9; IR (neat) 3430, 1770, 1046 $\mathrm{cm}^{-1}$; HRMS m/e calc'd for $\mathrm{C}_{9} \mathrm{H}_{14} \mathrm{O}_{4}\left(\mathrm{M}^{+}\right)$186.0892, found 186.0899 .

\section{Synthesis of selenotetrahydrofuran 19}

A stirred solution of bis-MOM alkene $18(1.610 \mathrm{~g}, 3.033 \mathrm{mmol})$ in $\mathrm{CH}_{2} \mathrm{Cl}_{2}(2 \mathrm{~mL})$ was treated with NPSP $(1.813 \mathrm{~g}, 5.999 \mathrm{mmol})$ and CSA $(0.139 \mathrm{~g}, 0.598 \mathrm{mmol})$ at room temperature, and the reaction was monitored by TLC. Upon consumption of the starting material, the solvent was removed under reduced pressure. The resulting yellow solid was purified by flash column chromatography (EtOAc/hexane, 1:6) to afford the desired product $\mathbf{1 9}(1.632 \mathrm{~g}, 85 \%)$ as a 1.12:1 mixture of diastereomers: ${ }^{1} \mathrm{H}$ NMR $\left(250 \mathrm{MHz}, \mathrm{CDCl}_{3}\right) \delta 7.71(\mathrm{~m}, 4 \mathrm{H}), 7.47(\mathrm{~m}, 2 \mathrm{H})$, $7.39(\mathrm{~m}, 6 \mathrm{H}), 7.21(\mathrm{~m}, 3 \mathrm{H}), 4.80(\mathrm{~m}, 2 \mathrm{H}), 4.10(\mathrm{dd}, J=8.7,4.1 \mathrm{~Hz}, 0.45 \mathrm{H}), 4.32(\mathrm{dd}, J=8.1$, $4.7 \mathrm{~Hz}, 0.55 \mathrm{H}), 3.95-3.67(\mathrm{~m}, 4 \mathrm{H}), 3.41(\mathrm{~s}, 1.35 \mathrm{H}), 3.38(\mathrm{~s}, 1.65 \mathrm{H}), 3.18(\mathrm{~m}, 1 \mathrm{H}), 3.14(\mathrm{~s}$, $1.35 \mathrm{H}), 3.13(\mathrm{~s}, 1.65 \mathrm{H}), 3.01-2.89(\mathrm{~m}, 2 \mathrm{H}), 1.06(\mathrm{~m}, 15 \mathrm{H}) ;{ }^{13} \mathrm{C} \mathrm{NMR}\left(63 \mathrm{MHz}, \mathrm{CDCl}_{3}\right) \delta$ 135.8, 135.7, 133.5, 133.2, 132.3, 132.2, 131.3, 131.2, 129.7, 129.6, 129.0, 128.9, 127.7, 127.60, 126.59, 126.5, 96.4, 96.0, 90.5, 90.1, 86.2, 83.0, 80.1, 79.6, 77.3, 64.1, 64.0, 60.4, 60.2, 55.7, 55.6, 47.3, 46.7, 31.3, 27.8, 27.7, 26.8, 20.2, 19.2, 19.1, 17.8; IR (neat) 1105, 1030 $\mathrm{cm}^{-1}$; HRMS m/e calc'd for $\mathrm{C}_{34} \mathrm{H}_{46} \mathrm{O}_{5} \mathrm{SeSi}\left(\mathrm{M}^{+}\right)$642.2279, found 642.2282 .

\section{Synthesis of bromotetrahydrofuran 20}

To a stirred solution of bis-MOM alkene $18(151 \mathrm{mg}, 0.284 \mathrm{mmol})$ and propylene oxide $(0.5$ $\mathrm{mL})$ in $\mathrm{CH}_{2} \mathrm{Cl}_{2}(3 \mathrm{~mL})$ was added NBS $(0.054 \mathrm{~g}, 0.30 \mathrm{mmol})$ at room temperature. The resulting mixture was stirred at room temperature in the dark for $8 \mathrm{~h}$. Upon consumption of the starting material, the solvent was removed under reduced pressure and the crude yellow oil was purified by flash column chromatography (EtOAc/hexane, 1:6) to afford the desired bromide $\mathbf{2 0}$ (130 $\mathrm{mg}, 86 \%$, diastereomeric ratio $>8: 1)$ as a colorless oil: ${ }^{1} \mathrm{H} \mathrm{NMR}\left(250 \mathrm{MHz}, \mathrm{CDCl}_{3}\right) \delta 7.71$ $(\mathrm{m}, 4 \mathrm{H}), 7.40(\mathrm{~m}, 6 \mathrm{H}), 4.78(\mathrm{dd}, J=9.2,6.8 \mathrm{~Hz}, 2 \mathrm{H}), 4.42(\mathrm{dd}, J=8.6,4.0 \mathrm{~Hz}, 1 \mathrm{H}), 4.00(\mathrm{dd}$, $J=7.2,5.4 \mathrm{~Hz}, 1 \mathrm{H}), 3.92(\mathrm{~m}, 1 \mathrm{H}), 3.85(\mathrm{~m}, 1 \mathrm{H}), 3.66(\mathrm{~d}, J=4.3 \mathrm{~Hz}, 1 \mathrm{H}), 3.41(\mathrm{~s}, 3 \mathrm{H}), 3.36$ (m, 2H), $3.19(\mathrm{~m}, 1 \mathrm{H}), 3.16(\mathrm{~s}, 3 \mathrm{H}), 1.13(\mathrm{~s}, 3 \mathrm{H}), 1.06(\mathrm{~s}, 9 \mathrm{H}), 0.92(\mathrm{~s}, 3 \mathrm{H}) ;{ }^{13} \mathrm{C}$ NMR $(63$ $\left.\mathrm{MHz}, \mathrm{CDCl}_{3}\right) \delta 135.7,135.6,133.5,133.1,129.7,129.6,127.7,127.6,95.9,90.8,83.8,79.7$, 76.4, 63.9, 60.3, 55.5, 47.4, 31.1, 26.8, 19.9, 19.5, 19.2; IR (neat) 1112, $1039 \mathrm{~cm}^{-1}$; HRMS m/e calc'sd for $\mathrm{C}_{28} \mathrm{H}_{41} \mathrm{O}_{5} \mathrm{Br}\left(\mathrm{M}^{+}\right)$536.2138, found 536.2186.

(4S,5S,6R)-5-Benzoyloxy-3,3-dimethyl-7-[(1,1-dimethylethyl)diphenylsilyl]oxy-4-methoxy-6(trimethylsilyl)oxy-1-heptene (25)

To a stirred solution of $\mathrm{BzCl}(0.618 \mathrm{~g}, 4.40 \mathrm{mmol})$ and a catalytic amount of DMAP (30 mg) in pyridine $(5 \mathrm{~mL})$ was added a solution of alcohol $23(1.131 \mathrm{~g}, 2.197 \mathrm{mmol})$ in pyridine $(5$ $\mathrm{mL}$ ) dropwise at room temperature. The resulting mixture was stirred at room temperature for 
$6 \mathrm{~h}$, diluted with diethyl ether $(30 \mathrm{~mL})$, and quenched with $\mathrm{H}_{2} \mathrm{O}(30 \mathrm{~mL})$. The separated aqueous layer was extracted with ether $(3 \times 30 \mathrm{~mL})$. The ether extracts were combined, washed with saturated $\mathrm{CuSO}_{4}$ solution $(30 \mathrm{~mL}), \mathrm{H}_{2} \mathrm{O}(2 \times 20 \mathrm{~mL})$, brine $(30 \mathrm{~mL})$, and dried over anhydrous $\mathrm{Na}_{2} \mathrm{SO}_{4}$. The solvent was removed under reduced pressure and the crude product was purified by flash column chromatography (EtOAc/hexane, 1:20) to afford ester $\mathbf{2 5}(1.299 \mathrm{~g}, 95 \%)$ as a colorless viscous oil: $[\alpha]^{23} \mathrm{D}-5.5^{\circ}\left(c 1.43, \mathrm{CHCl}_{3}\right) ;{ }^{1} \mathrm{H}$ NMR $\left(400 \mathrm{MHz}, \mathrm{CDCl}_{3}\right) \delta 8.03(\mathrm{~m}$, $2 \mathrm{H}), 7.68(\mathrm{~m}, 2 \mathrm{H}), 7.59(\mathrm{~m}, 3 \mathrm{H}), 7.44(\mathrm{~m}, 5 \mathrm{H}), 7.19(\mathrm{~m}, 3 \mathrm{H}), 5.19(\mathrm{dd}, J=17.7,10.8 \mathrm{~Hz}, 1 \mathrm{H})$, $5.40(\mathrm{dd}, J=5.5,10.8 \mathrm{~Hz}, 1 \mathrm{H}), 4.91(\mathrm{~m}, 2 \mathrm{H}), 3.97(\mathrm{dd}, J=11.0,5.2 \mathrm{~Hz}, 1 \mathrm{H}), 3.76(\mathrm{dd}, J=$ $10.5,5.2 \mathrm{~Hz}, 1 \mathrm{H}), 3.36(\mathrm{~s}, 3 \mathrm{H}), 3.27(\mathrm{~d}, J=3.4 \mathrm{~Hz}, 1 \mathrm{H}), 1.06(\mathrm{~s}, 3 \mathrm{H}), 1.03(\mathrm{~s}, 12 \mathrm{H}), 0.06(\mathrm{~s}$, $9 \mathrm{H}) ;{ }^{13} \mathrm{C}$ NMR $\left(63 \mathrm{MHz}, \mathrm{CDCl}_{3}\right) \delta 165.5,145.09,135.6,135.5,133.4,133.1,132.5,130.7$, 129.9, 129.7, 129.6, 129.5, 128.3, 128.2, 127.6, 127.5, 111.8, 84.9, 73.3, 72.5, 65.4, 61.5, 42.0, 26.7, 24.4, 23.3, 19.0, 0.26; IR (neat) 1725, 1112, $1027 \mathrm{~cm}^{-1}$; HRMS m/e calc'd for $\mathrm{C}_{36} \mathrm{H}_{51} \mathrm{O}_{5} \mathrm{Si}_{2}\left(\mathrm{MH}^{+}\right)$619.3274, found 619.3267.

(4S,5S,6R)-5-Benzoyloxy-3,3-dimethyl-7-[(1,1-dimethylethyl)diphenylsilyl]oxy-6-hydroxy-4methoxy-1-heptene (26)

To a stirred solution of benzoyl alkene $25(1.088 \mathrm{~g}, 1.757 \mathrm{mmol})$ in $\mathrm{MeOH}(10 \mathrm{~mL})$ was added PPTS ( $44 \mathrm{mg}, 0.18 \mathrm{mmol}$ ) at room temperature and the mixture was stirred at room temperature for $8 \mathrm{~h}$. Upon consumption of the starting material, the reaction was quenched with saturated $\mathrm{NaHCO}_{3}$ solution until gas evolution ceased. The reaction mixture was extracted with ether (3 $\times 30 \mathrm{~mL}$ ), and the combined ether extracts were washed with brine $(40 \mathrm{~mL})$ and dried over anhydrous $\mathrm{Na}_{2} \mathrm{SO}_{4}$. The solvent was removed under reduced pressure, and the crude oil was purified by flash column chromatography (EtOAc/hexane, 1:10) to afford alcohol $26(0.784$ $\mathrm{g}, 78.5 \%)$ as a colorless viscous oil: $[\alpha]^{23} \mathrm{D}-14.3^{\circ}\left(c 1.08, \mathrm{CHCl}_{3}\right) ;{ }^{1} \mathrm{H} \mathrm{NMR}(400 \mathrm{MHz}$, $\left.\mathrm{CDCl}_{3}\right) \delta 8.04(\mathrm{~m}, 2 \mathrm{H}), 7.66-7.59(\mathrm{~m}, 4 \mathrm{H}), 7.54(\mathrm{tt}, J=1.3,7.4 \mathrm{~Hz}, 1 \mathrm{H}), 7.43-7.33(\mathrm{~m}, 6 \mathrm{H})$, 7.31-7.27 (m, 2H), $5.94(\mathrm{dd}, J=10.8,17.6 \mathrm{~Hz}, 1 \mathrm{H}), 5.50(\mathrm{t}, J=4.2 \mathrm{~Hz}, 1 \mathrm{H}), 4.93(\mathrm{dd}, J=1.2$, $17.6 \mathrm{~Hz}, 1 \mathrm{H}), 4.85(\mathrm{dd}, J=1.2,10.8 \mathrm{~Hz}, 1 \mathrm{H}), 3.95(\mathrm{~m}, 1 \mathrm{H}), 3.68(\mathrm{~d}, J=5.5 \mathrm{~Hz}, 2 \mathrm{H}), 3.41(\mathrm{~s}$, $3 \mathrm{H}), 3.19(\mathrm{~d}, J=4.1 \mathrm{~Hz}, 1 \mathrm{H}), 2.58(\mathrm{br} \mathrm{s}, 1 \mathrm{H}), 1.08(\mathrm{~s}, 3 \mathrm{H}), 1.05(\mathrm{~s}, 3 \mathrm{H}), 1.04(\mathrm{~s}, 9 \mathrm{H}) ;{ }^{13} \mathrm{C} \mathrm{NMR}$ $\left(63 \mathrm{MHz}, \mathrm{CDCl}_{3}\right) \delta 165.9,144.9,135.6,135.5,133.0,132.82,132.78,130.3,129.9,129.8$, 128.2, 127.74, 127.69, 111.7, 86.9, 72.34, 72.29, 64.6, 61.9, 41.9, 26.8, 24.5, 23.3, 19.1. IR (Neat) $3494,1724 \mathrm{~cm}^{-1}$; HRMS m/e calc'd for $\mathrm{C}_{29} \mathrm{H}_{33} \mathrm{O}_{5} \mathrm{Si}\left(\mathrm{M}^{+}-\mathrm{C}_{4} \mathrm{H}_{9}\right) 489.2097$, found 489.2101.

\section{(2R,3R,4S,6R)-6-(bromomethyl)-2-((tert-butyldiphenylsilyloxy)methyl)-4-methoxy-5,5- dimethyltetrahydro-2H-pyran-3-yl benzoate (27)}

A stirred solution of hydroxy alkene $\mathbf{2 6}(0.594 \mathrm{~g}, 1.04 \mathrm{mmol})$ and propylene epoxide $(1 \mathrm{~mL})$ in DMF $(5 \mathrm{~mL})$ was treated with solid NBS $(0.374 \mathrm{~g}, 2.10 \mathrm{mmol})$ at room temperature. The flask was shielded from light and stirring continued for $20 \mathrm{~h}$. Upon consumption of the starting material, the reaction mixture was diluted with ether $(50 \mathrm{~mL})$ and washed with $\mathrm{H}_{2} \mathrm{O}(3 \times 20$ $\mathrm{mL})$. The ether layer was washed with brine $(20 \mathrm{~mL})$ and dried over anhydrous $\mathrm{Na}_{2} \mathrm{SO}_{4}$ The solvent was removed under reduced pressure, and the residue was purified by flash column chromatography (EtOAc/hexane, 1:10) to afford, as the major product, bromide $27(0.518 \mathrm{~g}$, $77 \%)$ as a colorless oil: ${ }^{1} \mathrm{H}$ NMR $\left(250 \mathrm{MHz}, \mathrm{CDCl}_{3}\right) \delta 8.01(\mathrm{~m}, 2 \mathrm{H}), 7.70-7.07(\mathrm{~m}, 13 \mathrm{H}), 5.26$ (t, $J=2.4 \mathrm{~Hz}, 1 \mathrm{H}), 4.13(\mathrm{~m}, 1 \mathrm{H}), 3.89(\mathrm{~m}, 1 \mathrm{H}), 3.80(\mathrm{~m}, 1 \mathrm{H}), 3.57(\mathrm{~s}, 3 \mathrm{H}), 3.48(\mathrm{dd}, J=10.8$, $1.8 \mathrm{~Hz}, 1 \mathrm{H}), 3.32(\mathrm{~d}, J=10.1 \mathrm{~Hz}, 1 \mathrm{H}), 3.13(\mathrm{~d}, J=2.8 \mathrm{~Hz}, 1 \mathrm{H}), 1.04-.97(\mathrm{~m}, 15 \mathrm{H}) ;{ }^{13} \mathrm{C} \mathrm{NMR}$ $\left(63 \mathrm{MHz}, \mathrm{CDCl}_{3}\right) \delta 165.7,135.6,135.5,133.2,133.1,130.0,129.7,128.5,127.7,127.5,83.4$, 81.2, 75.1, 67.8, 61.9, 59.0, 38.0, 32.2, 26.8, 26.7, 23.3, 19.29, 14.1. IR (neat) 1721, 1097, $1026 \mathrm{~cm}^{-1}$; HRMS m/e calc'd for $\mathrm{C}_{29} \mathrm{H}_{32} \mathrm{BrO}_{5} \mathrm{Si}_{\left(\mathrm{M}^{+}-\mathrm{C}_{4} \mathrm{H}_{9}\right)}$ 569.1186, found 569.1184.

(2S,4S,5S,6R)-5-Benzoyloxy-3,3-dimethyl-6-[[(1,1-dimethylethyl)diphenylsilyl] oxy]methyl-4methoxy-2-(phenylselenyl)methyl-2H-tetrahydro pyran (29a) and $(2 R, 4 S, 5 S, 6 R)-5-$ 


\section{Benzoyloxy-3,3-dimethyl-6-[[(1,1-dimethylethyl)diphenylsilyl]oxy]methyl-4-methoxy-2- (phenylselenyl)methyl-2H-tetrahydropyran (29b)}

A stirred solution of hydroxy alkene $26(0.150 \mathrm{~g}, 0.263 \mathrm{mmol})$ in $\mathrm{CH}_{2} \mathrm{Cl}_{2}(3 \mathrm{~mL})$ was treated with solid NPSP $(0.119 \mathrm{~g}, 0.394 \mathrm{mmol})$ and a catalytic amount of CSA $(0.005 \mathrm{~g}, 0.02 \mathrm{mmol})$ at room temperature for $8 \mathrm{~h}$. Upon consumption of the starting material, the reaction solution was concentrated in vacuo and the crude yellow solid was purified by flash column chromatography (EtOAc/hexane, 1:30) to afford the desired separable diastereomer mixtures 29a and 29b $(0.148 \mathrm{~g}, 78 \%, d r 1.8: 1)$. 29a: $[\alpha]^{23} \mathrm{D}+42.0^{\circ}\left(c 1.32, \mathrm{CHCl}_{3}\right) ;{ }^{1} \mathrm{H}$ NMR $(300$ $\left.\mathrm{MHz}, \mathrm{CDCl}_{3}\right) \delta 7.97(\mathrm{~m}, 2 \mathrm{H}), 7.65(\mathrm{~m}, 6 \mathrm{H}), 7.49(\mathrm{~m}, 2 \mathrm{H}), 7.42(\mathrm{~m}, 2 \mathrm{H}), 7.23(\mathrm{~m}, 8 \mathrm{H}), 5.34$ $(\mathrm{d}, J=6.6,4.8 \mathrm{~Hz} 1 \mathrm{H}), 4.27(\mathrm{dd}, J=10.1,5.2 \mathrm{~Hz}, 1 \mathrm{H}), 4.04(\mathrm{~d}, J=10.9 \mathrm{~Hz}, 1 \mathrm{H}), 3.89(\mathrm{~m}$, $2 \mathrm{H}), 3.57(\mathrm{~s}, 3 \mathrm{H}), 3.49(\mathrm{~d}, J=6.2 \mathrm{~Hz}, 1 \mathrm{H}), 3.01(\mathrm{dd}, J=12.0,3.1 \mathrm{~Hz}, 1 \mathrm{H}), 1.11(\mathrm{~s}, 3 \mathrm{H}), 1.03$, (s, 9H), $1.00(\mathrm{~s}, 3 \mathrm{H}) ;{ }^{13} \mathrm{C} \mathrm{NMR}\left(63 \mathrm{MHz}, \mathrm{CDCl}_{3}\right) \delta 165.8,135.6,133.0,132.8,132.7,132.3$, 130.0, 129.7, 129.62, 129.56, 128.9, 128.4, 127.62, 127.57, 126.5, 83.1, 79.9, 62.9, 60.7, 39.9, 28.4, 26.7, 22.6, 19.0; IR (neat) 1722, $1025 \mathrm{~cm}^{-1}$; HRMS m/e calc'd for $\mathrm{C}_{39} \mathrm{H}_{46} \mathrm{O}_{4} \mathrm{SeSi}\left(\mathrm{M}^{+}\right)$ 702.2279, found 702.2260. 29b: ${ }^{1} \mathrm{H}$ NMR $\left(300 \mathrm{MHz}, \mathrm{CDCl}_{3}\right) \delta 8.02(\mathrm{~m}, 2 \mathrm{H}), 7.63(\mathrm{~m}, 3 \mathrm{H})$, $7.43(\mathrm{~m}, 9 \mathrm{H}), 7.25(\mathrm{~m}, 4 \mathrm{H}), 7.09(\mathrm{~m}, 2 \mathrm{H}), 5.27(\mathrm{t}, J=2.4 \mathrm{~Hz}, 1 \mathrm{H}), 4.09(\mathrm{~m}, 1 \mathrm{H}), 3.80(\mathrm{~m}, 3 \mathrm{H})$, $3.56(\mathrm{~s}, 3 \mathrm{H}), 3.15(\mathrm{~d}, J=2.4 \mathrm{~Hz}, 1 \mathrm{H}), 3.06(\mathrm{dd}, J=12.0,10.5 \mathrm{~Hz}, 1 \mathrm{H}), 2.91(\mathrm{dd}, J=12.0,2.4$ $\mathrm{Hz}, 1 \mathrm{H}), 1.00(\mathrm{~s}, 3 \mathrm{H}), 0.97(\mathrm{~s}, 9 \mathrm{H}), 0.93(\mathrm{~s}, 3 \mathrm{H}) ;{ }^{13} \mathrm{C} \mathrm{NMR}\left(63 \mathrm{MHz}, \mathrm{CDCl}_{3}\right) \delta 165.7,135.5$, 135.4, 133.2, 133.1, 133.0, 132.7, 131.2, 130.1, 129.7, 129.6, 129.5, 128.9, 128.4, 127.6, 127.5, 126.6, 83.4 80.6, 75.1, 67.8, 61.7, 58.9, 37.9, 28.5, 26.7, 23.2, 19.3, 19.0; IR (neat) 1720, 1025 $\mathrm{cm}^{-1}$; HRMS m/e calc'd for $\mathrm{C}_{39} \mathrm{H}_{46} \mathrm{O}_{4} \mathrm{SeSi}\left(\mathrm{M}^{+}\right)$702.2279, found 702.2321.

\section{(2R,4S,5S,6R)-5-Benzoyloxy-2,3,3-trimethyl-6-[[(1,1-dimethylethyl)diphenylsilyl]oxy] methyl-4-methoxy-2H-tetrahydropyran (31)}

From 27: To a solution of bromide 27 (43 mg, $0.066 \mathrm{mmol}$ ) in $\mathrm{PhH}(5 \mathrm{~mL})$ was added $\mathrm{Bu}_{3} \mathrm{SnH}$ $(29 \mathrm{mg}, 0.10 \mathrm{mmol})$ and a catalytic amount of AIBN $(5 \mathrm{mg})$ and the mixture was heated to reflux for 1 hour. After cooling to room temperature, the solution was concentrated in vacuo and the crude oil was purified by flash column chromatography (EtOAc/hexane, 1:10) to afford the desired reduced product $31(28 \mathrm{mg}, 76 \%)$ as a colorless oil: ${ }^{1} \mathrm{H} \mathrm{NMR}\left(200 \mathrm{MHz}, \mathrm{CDCl}_{3}\right)$ $\delta 8.04(\mathrm{~m}, 2 \mathrm{H}), 7.64(\mathrm{~m}, 3 \mathrm{H}), 7.44(\mathrm{~m}, 3 \mathrm{H}), 7.34(\mathrm{~m}, 4 \mathrm{H}), 7.07(\mathrm{~m}, 3 \mathrm{H}), 5.29(\mathrm{dd}, J=2.5,2.4$ $\mathrm{Hz}, 1 \mathrm{H}), 4.10(\mathrm{~m}, 1 \mathrm{H}), 3.78(\mathrm{~d}, J=7.4 \mathrm{~Hz}, 2 \mathrm{H}), 3.67(\mathrm{~m}, 1 \mathrm{H}), 3.58(\mathrm{~s}, 3 \mathrm{H}), 3.16(\mathrm{~d}, J=2.7$ $\mathrm{Hz}, 1 \mathrm{H}), 0.95(\mathrm{~m}, 18 \mathrm{H}) ;{ }^{13} \mathrm{C} \mathrm{NMR}\left(63 \mathrm{MHz}, \mathrm{CDCl}_{3}\right) \delta 165.7,135.5,135.4,133.3,132.94$, 132.87, 130.2, 129.7, 129.4, 128.4, 128.3, 127.6, 127.4, 83.3, 75.7, 74.6, 67.9, 62.0, 58.9, 37.0, 26.7, 26.6, 23.2, 19.05, 19.02, 14.7; IR (neat) 1716, $1113 \mathrm{~cm}^{-1}$; HRMS $m / e$ calc'd for $\mathrm{C}_{32} \mathrm{H}_{39} \mathrm{O}_{5} \mathrm{Si}\left(\mathrm{M}^{+}-\mathrm{CH}_{3}\right)$ 531.2567, found 531.2589.

From 29b: To a solution of phenylselenide 29b (32 mg, $0.044 \mathrm{mmol})$ in $\mathrm{PhH}(5 \mathrm{ml})$ was added $\mathrm{Bu}_{3} \mathrm{SnH}(29 \mathrm{mg}, 0.10 \mathrm{mmol})$ and a catalytic amount of AIBN $(5 \mathrm{mg})$ and the mixture was heated to reflux for 1 hour. After cooling to room temperature, the reaction solution was concentrated in vacuo and the crude oil was purified by flash column chromatography (EtOAc/ hexane, 1:10) to afford the desired reduced product $\mathbf{3 1}(22 \mathrm{mg}, 85 \%)$ as a colorless oil. The NMR spectrum of the product of this reaction was identical to compound $\mathbf{3 1}$ obtained from the reduction of 27.

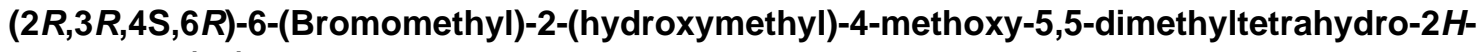 pyran-3-ol (48)}

To the solution of $27(0.9735 \mathrm{~g}, 1.5 \mathrm{mmol})$ in $\mathrm{MeOH}(10 \mathrm{~mL})$ was added concentrated $\mathrm{HCl}(1$ $\mathrm{mL}$ ) dropwise and the reaction mixture was stirred for $5 \mathrm{~h}$ at room temperature. To the mixture was added $2 \mathrm{~N} \mathrm{NaOH}$ solution dropwise until the solution became basic. Upon the completion of the reaction, the mixture was extracted with $\mathrm{Et}_{2} \mathrm{O}(30 \mathrm{~mL} \times 3)$. The combined organic layer was washed with $\mathrm{H}_{2} \mathrm{O}(30 \mathrm{~mL})$ and brine $(20 \mathrm{~mL})$, dried over $\mathrm{MgSO}_{4}$, and concentrated. The crude product was purified by column chromatography (hexane/EtOAc $=1 / 1$ ) to give diol 
$48(0.3865 \mathrm{~g}, 91 \%):{ }^{1} \mathrm{H}$ NMR (200 MHz, $\left.\mathrm{CDCl}_{3}\right) \delta 3.96(\mathrm{~m}, 2 \mathrm{H}), 3.87(\mathrm{~m}, 1 \mathrm{H}), 3.75(\mathrm{~m}, 2 \mathrm{H})$, $3.50(\mathrm{dd}, J=10.4,1.9 \mathrm{~Hz}, 1 \mathrm{H}), 3.39$ (s, $3 \mathrm{H}), 3.36(\mathrm{~d}, J=10.4 \mathrm{~Hz}, 1 \mathrm{H}), 3.16(\mathrm{~d}, J=4.0 \mathrm{~Hz}$, $1 \mathrm{H}), 2.86(\mathrm{~d}, J=3.0 \mathrm{~Hz}, 1 \mathrm{H}), 1.08(\mathrm{~s}, 3 \mathrm{H}), 0.99(\mathrm{~s}, 1 \mathrm{H}) ;{ }^{13} \mathrm{C} \mathrm{NMR}\left(63 \mathrm{MHz}, \mathrm{CDCl}_{3}\right) \delta 86.5$, 81.8, 75.1, 69.5, 64.3, 59.3, 37.8, 32.6, 23.6, 19.7; IR (neat) 1236, 1012; HRMS m/e calc'd for $\mathrm{C}_{10} \mathrm{H}_{19} \mathrm{BrO}_{4}\left(\mathrm{MH}^{+}\right)$282.0467, found 282.0463.

\section{(2S,3R,4S,6R)-6-(Bromomethyl)-2-(dimethoxymethyl)-4-methoxy-5,5- dimethyltetrahydro-2H-pyran-3-ol (50)}

To a stirred solution of $(\mathrm{COCl})_{2}(0.1269 \mathrm{~g}, 1.0 \mathrm{mmol})$ in $\mathrm{CH}_{2} \mathrm{Cl}_{2}(4 \mathrm{~mL})$ was added DMSO $(0.1563 \mathrm{~g}, 2.0 \mathrm{mmol})$ in $\mathrm{CH}_{2} \mathrm{Cl}_{2}(2 \mathrm{~mL})$ dropwise at $-78^{\circ} \mathrm{C}$. After stirring for $15 \mathrm{~min}$, a solution of $48(0.1182 \mathrm{~g}, 0.47 \mathrm{mmol})$ in $\mathrm{CH}_{2} \mathrm{Cl}_{2}(2 \mathrm{~mL})$ was added dropwise and the resulting mixture was stirred for $15 \mathrm{~min}$ at $-78{ }^{\circ} \mathrm{C}$. $\mathrm{Et}_{3} \mathrm{~N}(0.4047 \mathrm{~g}, 4.0 \mathrm{mmol})$ was added and the mixture was allowed to warm to room temperature over $1 \mathrm{~h}$. After addition of $\mathrm{H}_{2} \mathrm{O}(10 \mathrm{~mL})$, the mixture was extracted with $\mathrm{Et}_{2} \mathrm{O}(20 \mathrm{~mL} \times 3)$ and the combined ether extracts were washed with $\mathrm{H}_{2} \mathrm{O}$ $(20 \mathrm{~mL})$, brine $(15 \mathrm{~mL})$, dried over $\mathrm{Na}_{2} \mathrm{SO}_{4}$, filtered, and concentrated. The crude product was purified by column chromatography (hexane/EtOAc $=3 / 1$ ) to give $\mathbf{5 0}(0.1139 \mathrm{~g}, 74 \%):{ }^{1} \mathrm{H}$ NMR $\left(250 \mathrm{MHz}, \mathrm{CDCl}_{3}\right) \delta 4.61(\mathrm{~d}, J=4.5 \mathrm{~Hz}, 1 \mathrm{H}), 3.93(\mathrm{~m}, 1 \mathrm{H}), 3.74(\mathrm{~m}, 1 \mathrm{H}), 3.52(\mathrm{~s}, 3 \mathrm{H})$, $3.48(\mathrm{~s}, 3 \mathrm{H}) 3.47(\mathrm{~m}, 1 \mathrm{H}), 3.39(\mathrm{~m}, 1 \mathrm{H}), 3.38(\mathrm{~s}, 3 \mathrm{H}), 3.07(\mathrm{~d}, J=3.6 \mathrm{~Hz}, 1 \mathrm{H}), 2.88(\mathrm{~d}, J=3.0$ $\mathrm{Hz}, 1 \mathrm{H}), 1.09$ (s, 3H), 0.97 (s, 3H); ${ }^{13} \mathrm{C}$ NMR $\left(63 \mathrm{MHz}, \mathrm{CDCl}_{3}\right) \delta 104.5,86.2,82.2,75.7,66.9$, $59.2,56.1,54.6,37.8,32.5,23.6,19.6$.

\section{(2S,4S,5S,6S)-3,3-Dimethyl-6-carbaldehyde-4-methoxy-5-methoxymethoxy-2- (phenylselenyl)methyl-2H-tetrahydrapyran (55)}

To a solution of $(\mathrm{COCl})_{2}(0.165 \mathrm{~g}, 1.30 \mathrm{mmol})$ in $\mathrm{CH}_{2} \mathrm{Cl}_{2}(2 \mathrm{~mL})$ was added a solution of DMSO $(0.203 \mathrm{~g}, 2.60 \mathrm{mmol})$ in $\mathrm{CH}_{2} \mathrm{Cl}_{2}(0.5 \mathrm{~mL})$ dropwise at $-78{ }^{\circ} \mathrm{C}$. After $5 \mathrm{~min}$, a solution of MOM alcohol $54(0.260 \mathrm{~g}, 0.645 \mathrm{mmol})$ in $\mathrm{CH}_{2} \mathrm{Cl}_{2}(2 \mathrm{~mL})$ was added dropwise followed by addition of $\mathrm{Et}_{3} \mathrm{~N}(0.162 \mathrm{~g}, 1.60 \mathrm{mmol})$. The resulting cloudy solution was warmed to room temperature and stirred for $45 \mathrm{~min}$. The reaction was quenched by addition of $\mathrm{H}_{2} \mathrm{O}(30 \mathrm{~mL})$. The organic phase was separated, and the aqueous phase was extracted with $\mathrm{Et}_{2} \mathrm{O}(2 \times 30 \mathrm{~mL})$. The combined ether phase was washed with $\mathrm{H}_{2} \mathrm{O}(20 \mathrm{~mL})$, brine $(20 \mathrm{~mL})$, and dried over anhydrous $\mathrm{Na}_{2} \mathrm{SO}_{4}$ The solvent was removed under reduced pressure, and the crude yellow oil was purified by flash column chromatography (EtOAc/hexane, 1:6) to afford aldehyde $\mathbf{5 5}$ $(0.188 \mathrm{~g}, 73 \%)$ as a pale yellow oil: $[\alpha]^{23} \mathrm{D}+128.8^{\circ}\left(c 1.39, \mathrm{CHCl}_{3}\right) ;{ }^{1} \mathrm{H} \mathrm{NMR}(200 \mathrm{MHz}$, $\left.\mathrm{CDCl}_{3}\right) \delta 9.90(\mathrm{~s}, 1 \mathrm{H}), 7.45(\mathrm{~m}, 2 \mathrm{H}), 7.24(\mathrm{~m}, 3 \mathrm{H}), 4.77(\mathrm{dd}, J=16.2,6.7 \mathrm{~Hz}, 2 \mathrm{H}), 4.46(\mathrm{~d} J$ $=6.4 \mathrm{~Hz}, 1 \mathrm{H}), 4.00(\mathrm{dd}, J=8.8,6.4 \mathrm{~Hz}, 1 \mathrm{H}), 3.79(\mathrm{dd}, J=10.4,2.7 \mathrm{~Hz}, 1 \mathrm{H}), 3.49(\mathrm{~s}, 3 \mathrm{H}), 3.12$ $(\mathrm{m}, 1 \mathrm{H}), 2.96(\mathrm{dd}, J=12.2,2.7 \mathrm{~Hz}, 1 \mathrm{H}), 2.84(\mathrm{~d}, J=8.8 \mathrm{~Hz}, 1 \mathrm{H}), 0.96(\mathrm{~s}, 3 \mathrm{H}), 0.91(\mathrm{~s}$, $3 \mathrm{H}) ;{ }^{13} \mathrm{C}$ NMR $\left(63 \mathrm{MHz}, \mathrm{CDCl}_{3}\right) \delta 201.7,133.1,130.7,127.0,97.7,85.7,80.3,78.0,75.6$, 61.6, 56.0, 41.2, 28.0, 23.8, 15.2; IR (neat) 1734, $1109 \mathrm{~cm}^{-1}$; HRMS m/e calc'd for $\mathrm{C}_{18} \mathrm{H}_{26} \mathrm{O}_{5} \mathrm{Se}\left(\mathrm{M}^{+}\right)$402.0945, found 402.0974 .

\section{(4RS,4aS,6S,8S,8aR)-Hexahydro-8-methoxy-7,7-dimethyl-6-[(phenyl selenyl)methyl]pyrano [3,2-d]-m-dioxin-4-ol (56)}

A stirred mixture of MOM aldehyde $55(103 \mathrm{mg}, 0.257 \mathrm{mmol})$ and paraformaldehyde powder (50 mg, excess) in $\left.\mathrm{Et}_{2} \mathrm{O}\right)(0.5 \mathrm{~mL})$ was cooled to $0{ }^{\circ} \mathrm{C}$ and treated dropwise with concentrated $\mathrm{HCl}(2 \mathrm{~mL})$. The resulting mixture was stirred at $0{ }^{\circ} \mathrm{C}$ for $30 \mathrm{~min}$, then diluted with ether $(20$ $\mathrm{mL})$. The reaction was quenched with saturated $\mathrm{NaHCO}_{3}$ solution $(50 \mathrm{~mL})$ and extracted with ether $(3 \times 15 \mathrm{~mL})$. The combined ether phase was washed with brine $(20 \mathrm{~mL})$ and dried over $\mathrm{Na}_{2} \mathrm{SO}_{4}$ The solvent was removed under reduced pressure and the residue was purified by flash column chromatography (EtOAc/hexane, 1:4) to afford $\mathbf{5 6}(90 \mathrm{mg}, 92 \%)$ as a colorless oil. The initially formed 2:1 ratio of diastereomers changed to 1:1 after several hours in $\mathrm{CDCl}_{3}$ solution: ${ }^{1} \mathrm{H} \mathrm{NMR}\left(200 \mathrm{MHz}, \mathrm{CDCl}_{3}\right) \delta 7.50(\mathrm{~m}, 2 \mathrm{H}), 7.24(\mathrm{~m}, 3 \mathrm{H}), 5.22(\mathrm{~d}, J=6.0 \mathrm{~Hz}, 0.5 \mathrm{H})$, 
$5.11(\mathrm{~d}, J=6.0 \mathrm{~Hz}, 0.5 \mathrm{H}), 5.05(\mathrm{~d}, J=1.8 \mathrm{~Hz}, 0.5 \mathrm{H}), 4.90(\mathrm{br} \mathrm{d}, J=6.3 \mathrm{~Hz}, 0.5 \mathrm{H}), 4.81(\mathrm{~d}$, $J=6.0 \mathrm{~Hz}, 0.5 \mathrm{H}), 4.73(\mathrm{~d}, J=6.0 \mathrm{~Hz}, 0.5 \mathrm{H}), 3.95(\mathrm{dd}, J=3.1,2.2 \mathrm{~Hz}, 0.5 \mathrm{~Hz}), 3.75(\mathrm{~m}, 2.5 \mathrm{H})$, $3.58(\mathrm{~m}, 1 \mathrm{H}), 3.40(\mathrm{~s}, 3 \mathrm{H}), 3.07(\mathrm{~d}, J=3.3 \mathrm{~Hz}, 0.5 \mathrm{H}), 3.01(\mathrm{~m}, 1 \mathrm{H}), 2.91(\mathrm{~d}, J=5.4 \mathrm{~Hz}, 0.5 \mathrm{H})$, $1.24(\mathrm{~s}, 1.5 \mathrm{H}), 1.23(\mathrm{~s}, 1.5 \mathrm{H}), 0.98(\mathrm{~s}, 1.5 \mathrm{H}), 0.96(\mathrm{~s}, 1.5 \mathrm{H}) . ;{ }^{13} \mathrm{C} \mathrm{NMR}\left(63 \mathrm{MHz}, \mathrm{CDCl}_{3}\right) \delta$ 132.9, 132.7, 130.6, 130.0, 129.0, 128.9, 126.8, 126.6, 93.8, 92.0, 89.9, 84.9, 83.3, 83.2, 80.7, $79.9,72.3,69.1,62.8,62.0,59.50,59.48,37.71,37.69,28.1,28.0,27.2,27.1,22.3,22.0$; IR (neat) $3418,1093,1036 \mathrm{~cm}^{-1}$; HRMS m/e calc'd for $\mathrm{C}_{17} \mathrm{H}_{24} \mathrm{O}_{5} \mathrm{Se}\left(\mathrm{M}^{+}\right) 388.0788$, found 388.0797 .

\title{
Supplementary Material
}

Refer to Web version on PubMed Central for supplementary material.

\begin{abstract}
Acknowledgements
Generous financial support from the National Institutes of Health is gratefully acknowledged. We also thank Merck Research Laboratories and Pfizer Inc. for partial financial support.
\end{abstract}

\section{References and Notes}

1. (a) Perry NB, Blunt JW, Munro MHG. J Am Chem Soc 1988;110:4850. (b) Perry NB, Blunt JW, Munro MHG, Thompson AM. J Org Chem 1990;55:223.

2. (a) Simpson JS, Garson MJ, Blunt JW, Munro MHG, Hooper JNA. J Nat Prod 2000;63:704. [PubMed: 10843596] (b) West LM, Northcote PT, Hood KA, Miller JH, Page MJ. J Nat Prod 2000;63:707. [PubMed: 10843597]

3. (a) Sakemi S, Ichiba T, Kohmoto S, Saucy G, Higa T. J Am Chem Soc 1988;110:4851. (b) Matsunaga S, Fusetani N, Nakao Y. Tetrahedron 1992;48:8369. (c) Kobayashi J, Itagaki F, Shigemori H, Sasaki T. J Nat Prod 1993;56:976. (d) Vuong D, Capon RJ, Lacey E, Gill JH, Heiland K, Friedel T. J Nat Prod 2001;64:640. [PubMed: 11374963]

4. (a) Fusetani N, Sugawara T, Matsunaga S. J Org Chem 1992;57:3828. (b) Tsukamoto S, Matsunaga S, Fusetani N, Toh-e A. Tetrahedron 1999;55:13697. (c) Paul GK, Gunasekera SP, Longley RE, Pomponi SA. J Nat Prod 2002;65:59. [PubMed: 11809067]

5. Burres NS, Clement JJ. Cancer Res 1989;49:2935. [PubMed: 2720652]

6. Glavine F, Freeman GJ, Razi-Wolf Z, Bennacerraf B, Nadler L, Reiser H. Eur J Immunol 1993;23:283. [PubMed: 7678228]

7. (a) Furusaki A, Watanabe T, Matsumoto T, Yanagiya M. Tetrahedron Lett 1968:6301. (b) Corradi AB, Mangia A, Nardelli N, Pelizzi G. Gazz Chim Ital 1971;101:591.

8. Mycalamide A: (a) Hong CY, Kishi Y. J Org Chem 1990;55:4242. (b) Nakata T, Fukui H, Nakawara T, Matsukura H. Heterocycles 1996;42:159. (c) Roush WR, Pfeifer LA. Org Lett 2000;2:859. [PubMed: 10754688] (d) Sohn J-H, Waizumi N, Zhong HM, Rawal VH. J Am Chem Soc 2005;127:7290. [PubMed: 15898759] (e) Kagawa N, Ihara M, Toyota M. Org Lett 2006;8:875. [PubMed: 16494463] Formal synthesese: (f) Nakata T, Matsukura H, Jian D, Nagashima H. Tetrahedron Lett 1994;35:8229. (g) Trost BM, Yang H, Probst GD. J Am Chem Soc 2004;126:48. [PubMed: 14709053]

9. Mycalamide B and theopederin D: Kocienski P, Narquizian R, Raubo P, Smith C, Farrugia LJ, Muir K, Boyle FT. J Chem Soc, Perkin Trans 1 2000:2357. and references therein. See also ref. 8(a) for mycalamide $\mathrm{B}$

10. Onnamide A: Hong CY, Kishi Y. J Am Chem Soc 1991;113:9694.

11. Mycalamine unit and model study: (a) Rech JC, Floreancig PE. Org Lett 2003;5:1495. [PubMed: 12713307] (b) Gardiner JM, Mills R, Fessard T. Tetrahedron Lett 2004:1215. (c) Toyota M, Hirota M, Hirano H, Ihara M. Org Lett 2000;2:2031. [PubMed: 10891222] (d) Breitfelder S, Schlapbach A, Hoffmann RW. Synthesis 1998:468.and references therein (e) Roush WR, Marron TG. Tetrahedron Lett 1993;34:5421. 
12. (a) Fukui H, Tsuchiya Y, Fujita K, Nakagawa T, Koshino H, Nakata T. Bioorg \& Med Chem Lett 1997;7:2081. (b) Abell AD, Blunt JW, Foulds GJ, Munro MHG. J Chem Soc, Perkin Trans 1: Org and Bioorg Chem 1997:1647. (c) Takahashi S, Okada A, Nakata T. Heterocycles 2004;63:2111.

13. (a) Thompson AM, Blunt JW, Munro MHG, Perry NB, Pannel LK. J Chem Soc, Perkin Trans 1 1992:1335. (b) Thompson AM, Blunt JW, Munro MHG, Clark BM. J Chem Soc, Perkin Trans 1 1994:1025. (c) Thompson AM, Blunt JW, Munro MHG, Perry NB. J Chem Soc, Perkin Trans 1 1995:1223.

14. Fuji K, Nakano S, Fujita E. Synthesis 1975:276.

15. (a) Dulphy H, Gras JL, Lejon T. Tetrahedron 1996;52:8517.Fieser, LR.; Fieser, M. Fieser and Fieser's Reagents for Organic Synthesis. 1. Wiley \& Sons; New York: 1967. p. 583-584.

16. (a) Keck GE, Boden EP. Tetrahedron Lett 1984;25:265. (b) Keck GE, Boden EP. Tetrahedron Lett 1984;25:1879. (c) Keck GE, Abbott DE, Boden EP, Enholm EJ. Tetrahedron Lett 1984;25:3927. (d) Marshall JA, Gung WY. Tetrahedron Lett 1989;30:2183. (e) Marshall JA, Luke GP. J Org Chem 1991;56:483. and references therein

17. Bloch R, Brillet C. Synlett 1991:829.

18. Williard PG, Fryhle GB. Tetrahedron Lett 1980:3731.

19. Nicolaou KC, Petasis NA, Claremon DA. Tetrahedron 1985;41:4835.

20. (a) Rychnovsky SD, Bartlett PA. J Am Chem Soc 1981;103:3963. (b) Bartlett PA. Asymmetric Synthesis 1984;4:411-454.and references therein

21. Monti H, Leandri G, Klos-Ringquet M, Corriol C. Synth Commun 1983;13:1021.

22. (a) The ORTEP diagram and X-ray crystallographic data of 28 are in the Supporting Information. (b) Chamberlin AR, Dezube M, Dussault P, McMills MC. J Am Chem Soc 1983;105:5819. (c) Reitz AB, Nortey SO, Maryanoff BE, Liotta D, Monahan R III. J Org Chem 1987;52:4191.

23. (a) Ramaiah M. Tetrahedron 1987;43:3541. (b) Neumann WP. Synthesis 1987:665.

24. (a) Brown RS, Gedye R, Slebocka-Tilk H, Buschek JM, Kopecky KR. J Am Chem Soc 1984;106:4515. (b) Slebocka-Tilk H, Ball RG, Brown RS. Ibid 1985;107:4504. (c) Bellucci G, Bianchini R, Ambrosetti R. Ibid 1985;107:2464. (d) Bellucci G, Chiappe C, Marioni F. Ibid 1987;109:515.

25. (a) Nishiyama S, Ikeda Y, Yoshida S, Yamamura S. Tetreahedron Lett 1989;30:105. (b) Angyal SJ, Beveridge RJ. Carbohydr Res 1978;65:229. (c) Grieco PA, Yokoyama Y, Withers GP, Okuniewicz FJ, Wang C-LJ. J Org Chem 1978;43:4178.

26. Gras J-L, Nouguier R, Mchich M. Tetradedron Lett 1987;28:6601.

27. (a) Tidwell TT. Org, React 1990;39:297. (b) Timioka K, Takai K, Oshima K, Nozaki H. Tetrahedron Lett 1981;22:1605.and references therein

28. Paulmier, C. Selenium Reagents and Intermediates in Organic Synthesis. Pergamon Press; New York: 1986. Chapter 5.

29. (a) Martin OR, Szarek WA. Carbohydr Res 1984;130:195. (b) Halmos T, Filippi J, Bach J, Antonakis K. Carbohydr Res 1982;99:180. (c) Cree GM, Mackie DW, Perlin AS. Can J Chem 1969;47:511. (d) Graig GW, Sternberg ED, Jones GH, Moffatt JG. J Org Chem 1986;51:1258. (e) Vatele J-M. Tertrahedron 1986;42:4443.

30. Danishefsky SJ, DeNinno MP, Chen S-h. J Am Chem Soc 1988;110:3929.

31. This work was taken in large part from the doctoral dissertation of H. M. Zhong. See, ZhongHMPhD DissertationThe Ohio State UniversityColumbus, OH1995 


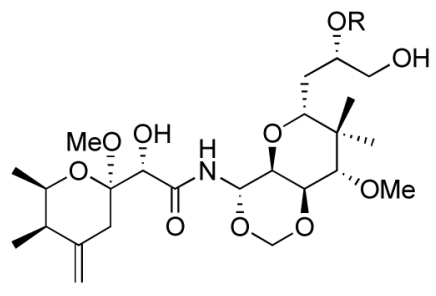

mycalamide $A, R=H(1)$

mycalamide $\mathrm{B}, \mathrm{R}=\mathrm{Me}(\mathbf{2})$

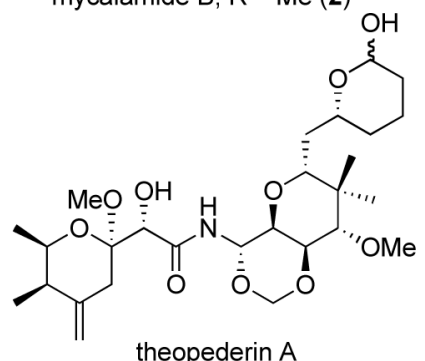

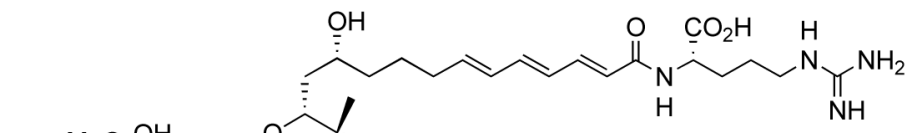

onnamide A

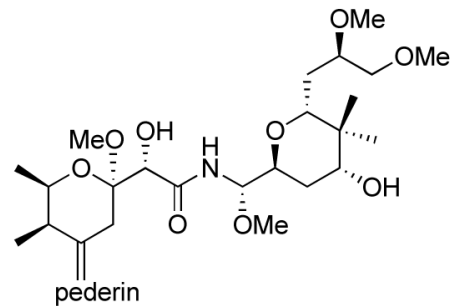

Figure 1.

Structures of mycalamides A and B, onnamide A pederin, theopederin A. 


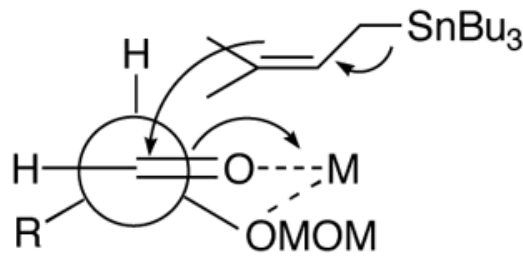

12

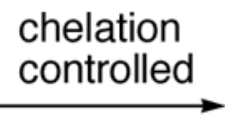

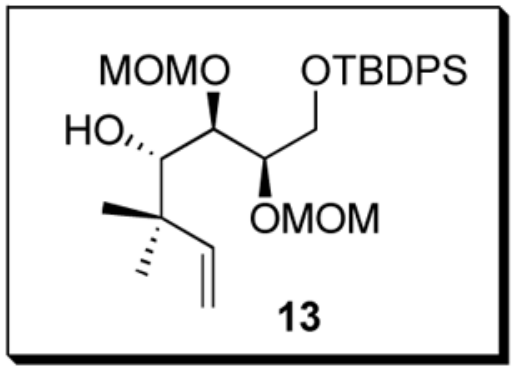

Figure 2.

Chelation Controlled Addition of Aldehyde 12 

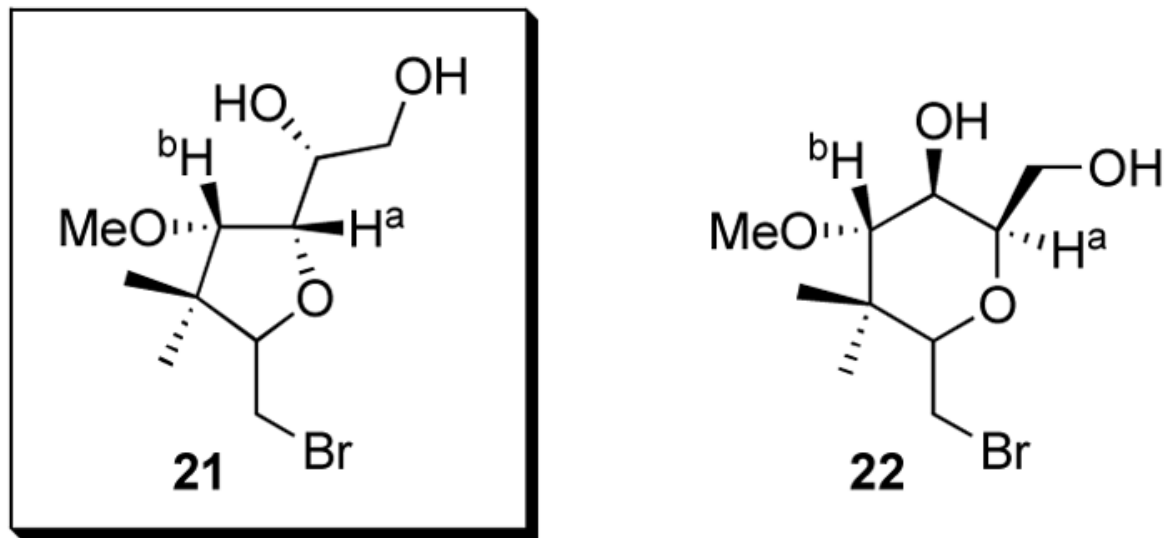

Figure 3.

Determination of the Structure of Cyclization Product by ${ }^{1} \mathrm{H}$ NMR Decoupling Pattern of Derivative of $\mathbf{2 1}$ or $\mathbf{2 2}$ 


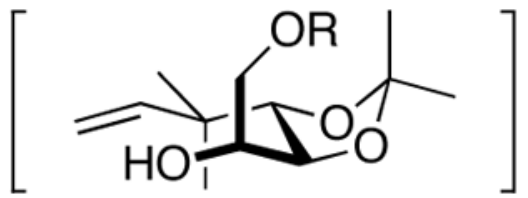

$35 a$
vS

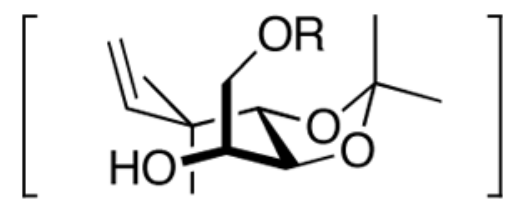

$35 b$

Figure 4.

Two Possible Transition States of $\mathbf{3 5}$ in Electrophilic Cyclization 

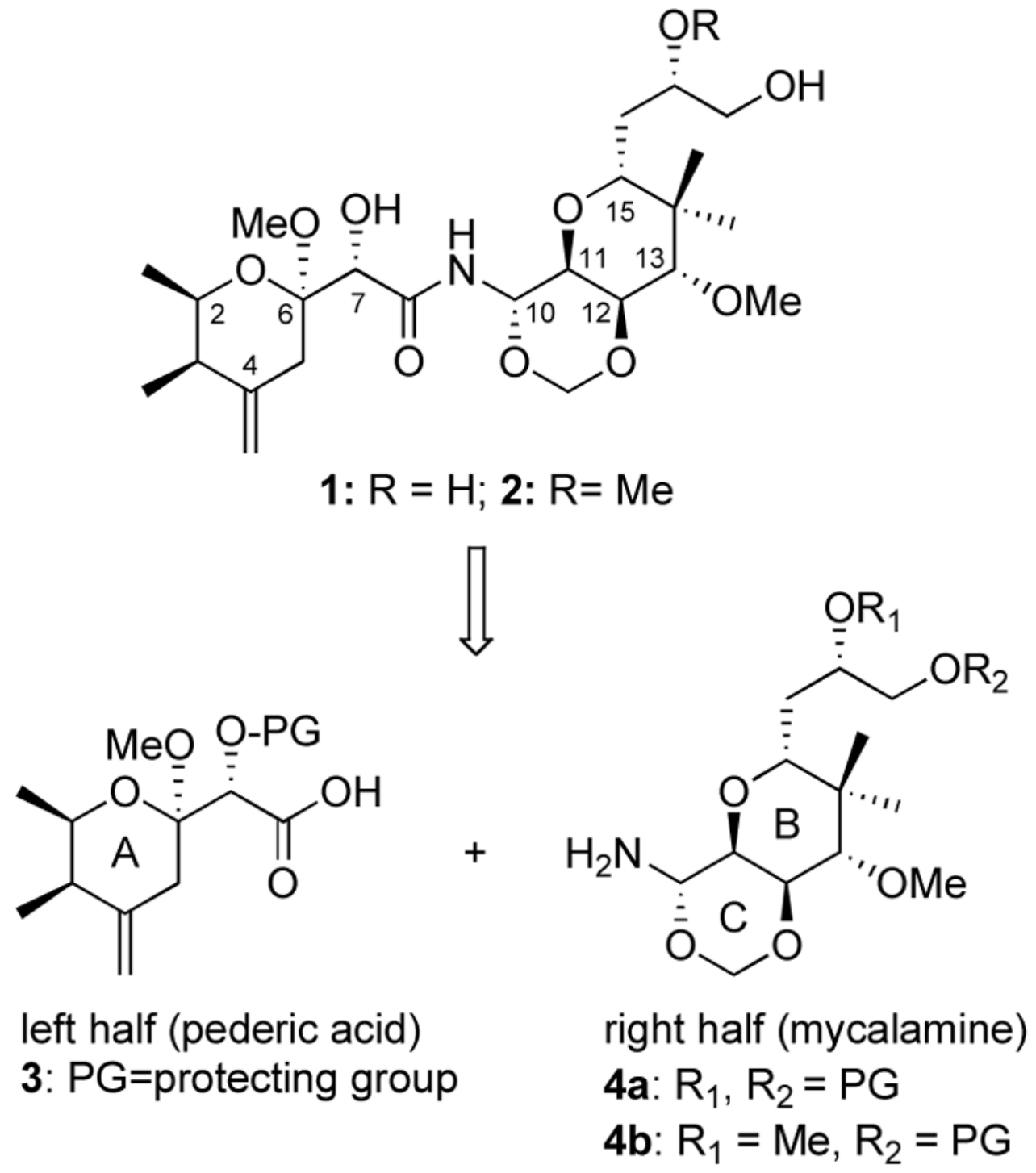

Scheme 1.

Hong-Kishi Disconnection of Mycalamides to Pederic Acid and Mycalamine Units 


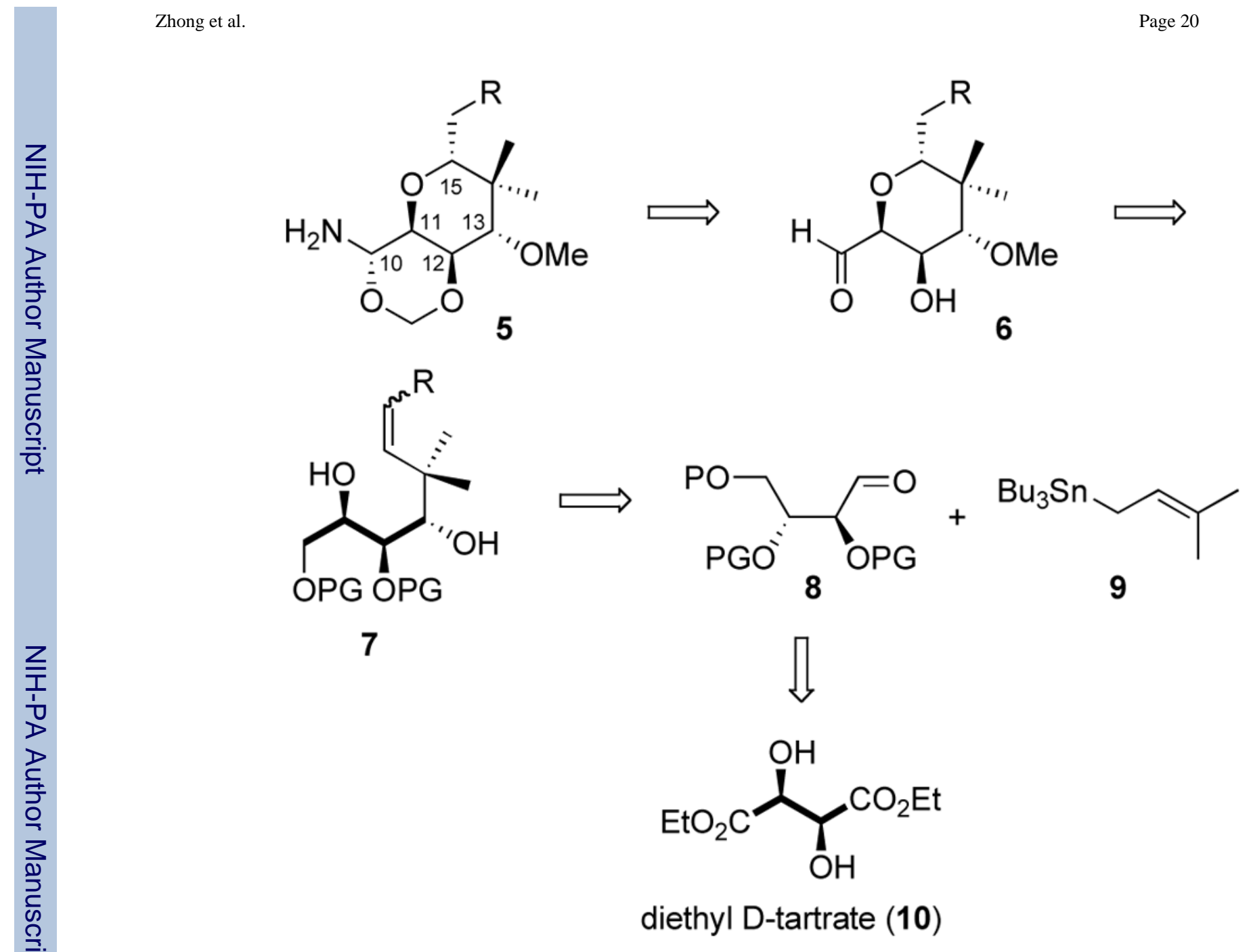

Scheme 2.

Retrosynthetic Analysis of the Right Part of Mycalamides 
<smiles>CCOC(=O)[C@H](O)[C@@H](O)C(=O)OCC</smiles>

1. $(\mathrm{MeO})_{2} \mathrm{CH}_{2}, \mathrm{P}_{2} \mathrm{O}_{5}$ $\mathrm{CH}_{2} \mathrm{Cl}_{2}$ (quant)

2. $\mathrm{LiAlH}_{4}, \mathrm{Et}_{2} \mathrm{O}$

reflux $(86 \%)$<smiles>COC(OC)[C@@H](CO)OC</smiles>

11
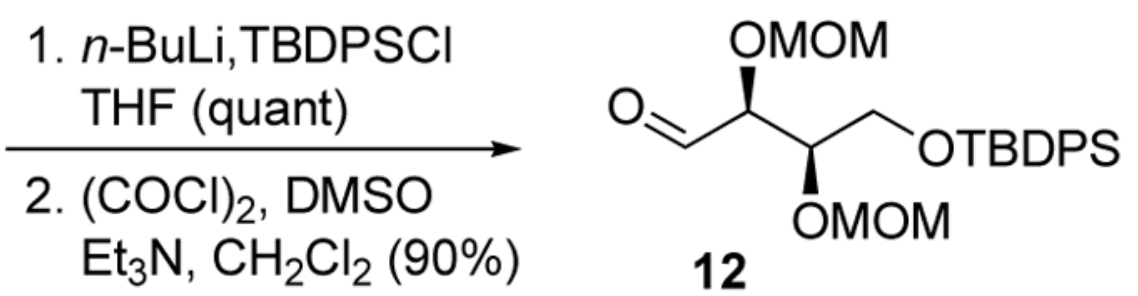

12

Scheme 3.

Preparation of Aldehyde 12 from Diethyl D-Tartrate 


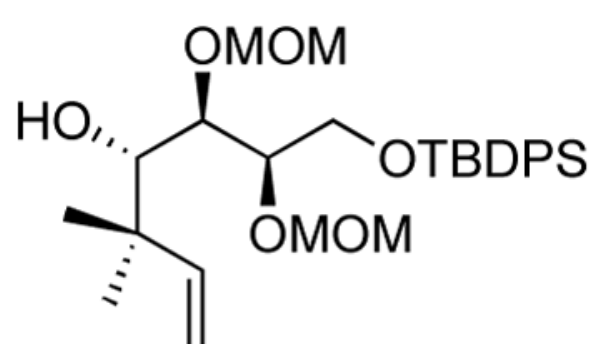

13
1. TBAF, THF (quant)

2. TPAP, NMO, MS $\mathrm{CH}_{2} \mathrm{Cl}_{2}$, rt $(61 \%)$

3. $\mathrm{BBr}_{3} \cdot \mathrm{Me}_{2} \mathrm{~S}$ $\mathrm{CH}_{2} \mathrm{Cl}_{2}, 0{ }^{\circ} \mathrm{C}$ to $\mathrm{rt}$ (69\%)<smiles>C=CC(C)(C)[C@H]1OC(=O)[C@@H](O)[C@H]1O</smiles>

$\mathrm{Ag}_{2} \mathrm{O}, \mathrm{Mel}$

$\mathrm{CH}_{2} \mathrm{Cl}_{2}$, rt, $24 \mathrm{~h}$<smiles>C=CC(C)(C)[C@H]1OC(=O)[C@@H](OC)[C@@H]1OC</smiles>

$15(8 \%)$<smiles>C=CC(C)(C)[C@H]1OC(=O)[C@@H](OC)[C@@H]1O</smiles>

$16(8 \%)$

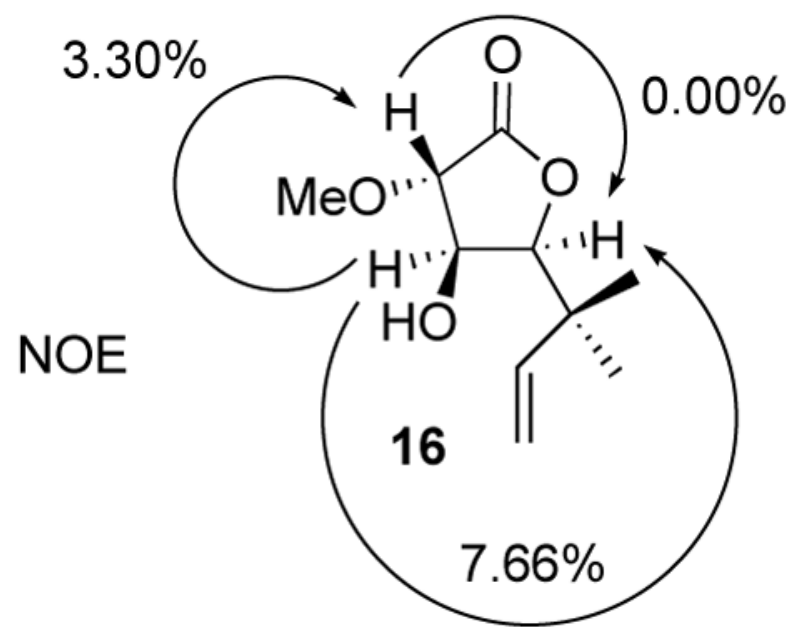

Scheme 4.

Determination of Stereochemistry of Addition Product 13 
<smiles>C=CC(C)(C)[C@H]1OC(=O)[C@@H](OC)[C@@H]1O</smiles>
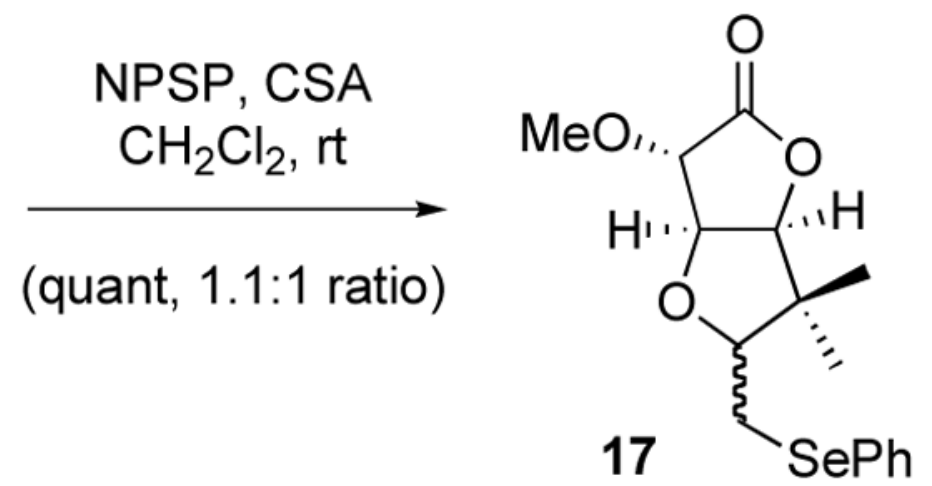

Scheme 5.

Corroboration of the Assigned Stereochemistry of C-13 


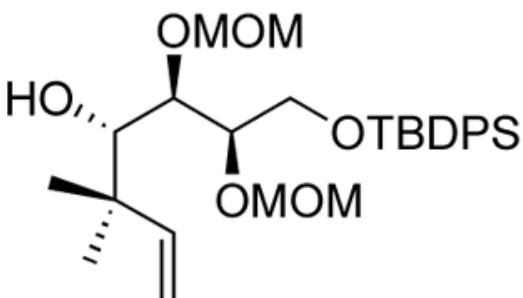

13

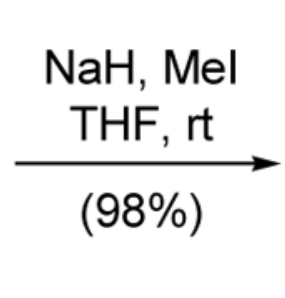

(98\%)

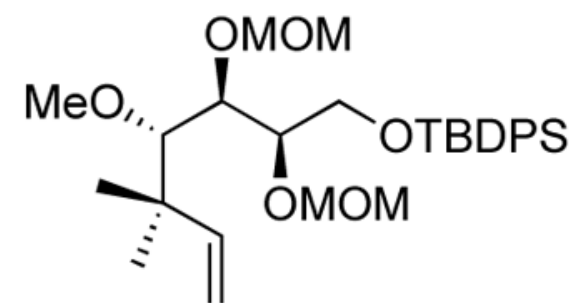

18

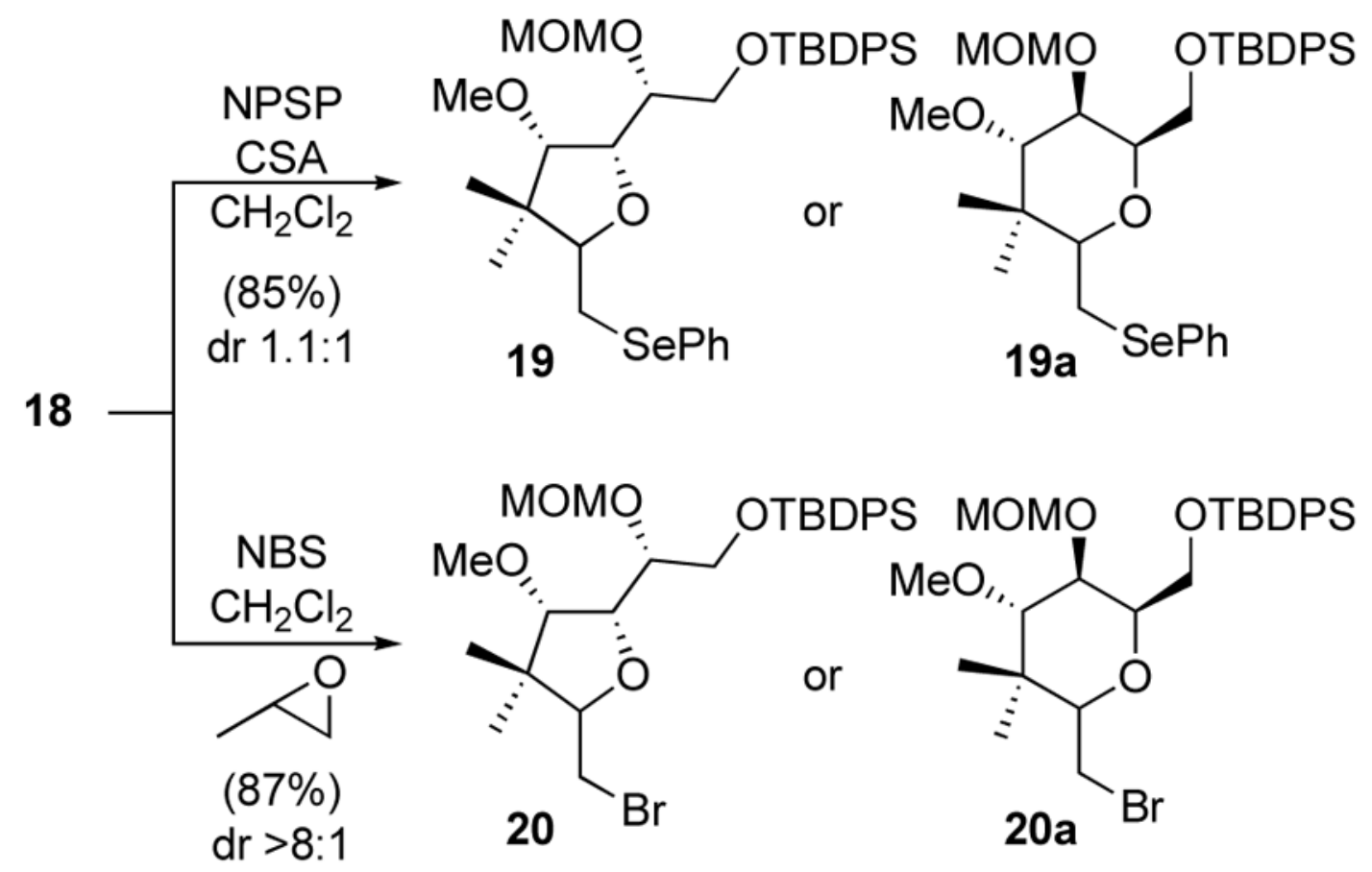

Scheme 6.

Electrophilic Cyclization of Bis-MOM Alkene $\mathbf{1 8}$ 
<smiles>[R]O[C@@H](C[OH+])[C@@H](O)[C@H](OC)C(C)(C)C=C</smiles>

18: $\mathrm{R}=\mathrm{MOM}$ 18': $\mathrm{R}=\mathrm{H}$

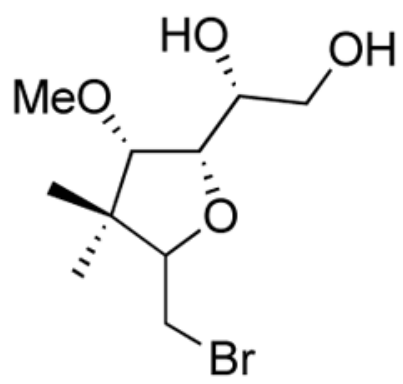

21 , sole product

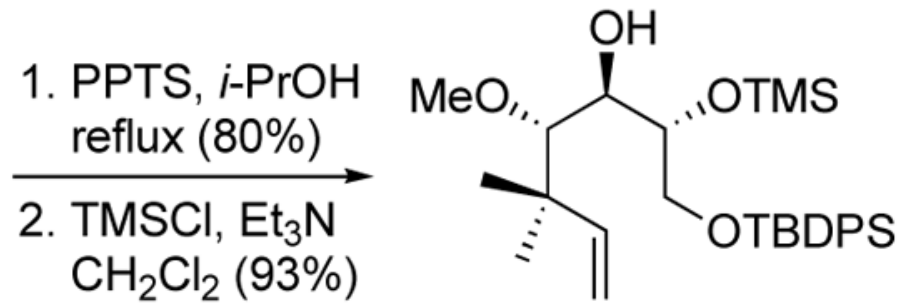

23

1. $\mathrm{NaH}, \mathrm{MOMCl}$ THF, rt 2. TBAF, THF

$(53 \%)$

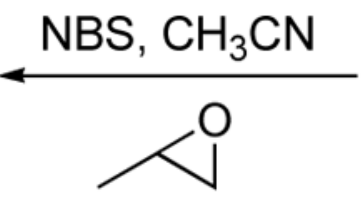<smiles>C=CC(C)(C)[C@@H](OC)[C@@H](OC)[C@@H](O)CO</smiles>

24

Scheme 7.

Differentiation of the Two Hydroxyl Groups and Cyclization 
<smiles>C=CC(C)(C)[C@@H](OC)[C@@H](O)[C@H](C[OH+])O[Mg]</smiles>

23

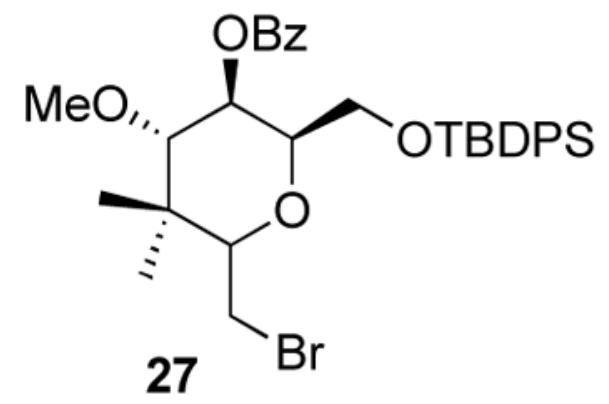

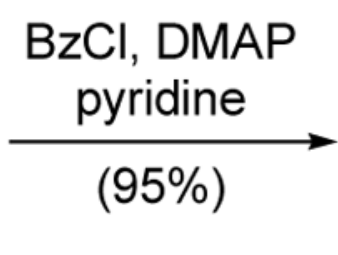

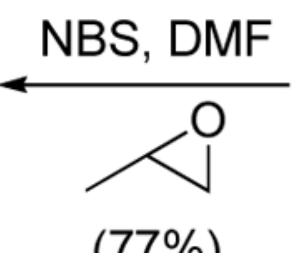

(77\%)

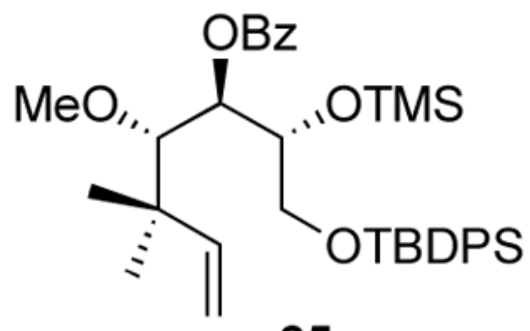

25

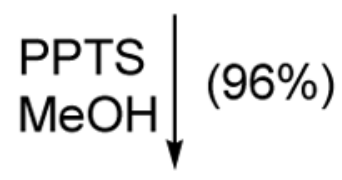

26

Scheme 8.

Electrophilic Cyclization of Benzoyl Alcohol 26 to Give Six-Membered Product 27 

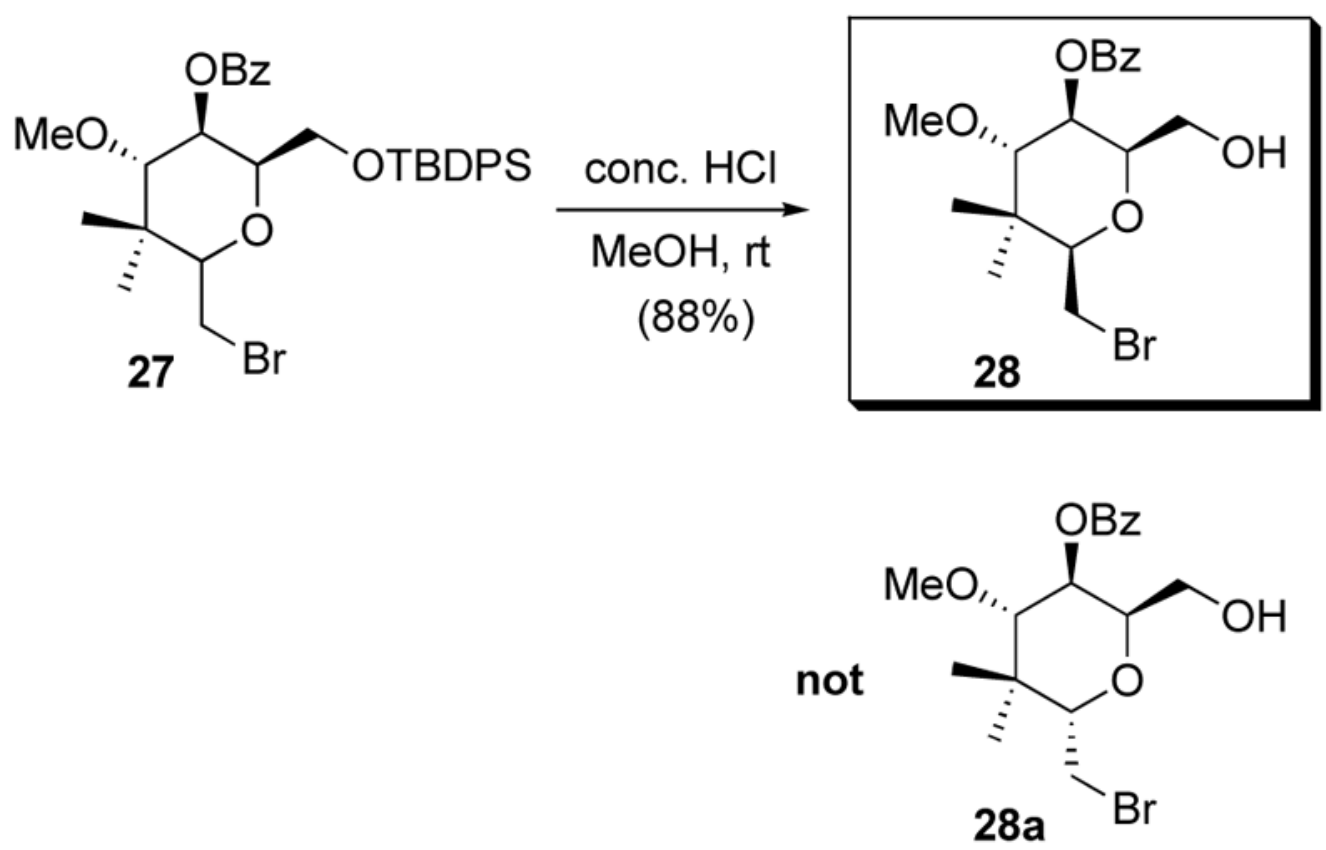

Scheme 9.

Establishment of Absolute Stereochemistry of Cyclization Product 


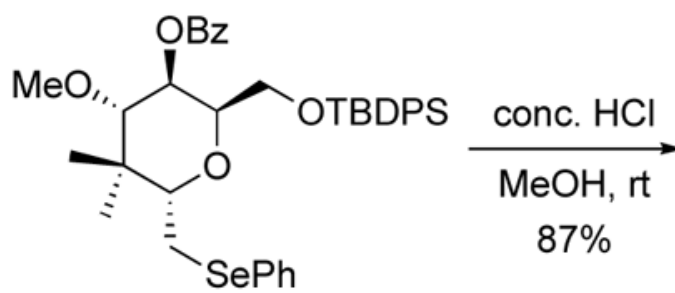

29a

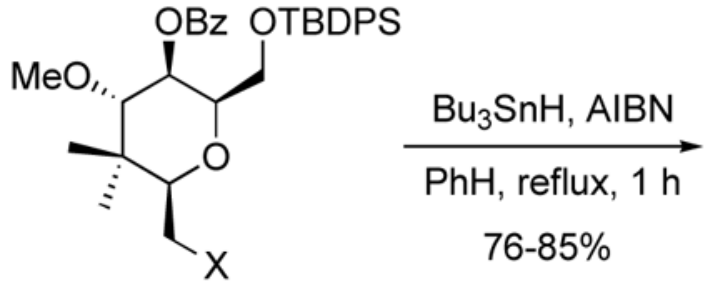

29b: $X=\mathrm{SePh}$

$27: X=B r$
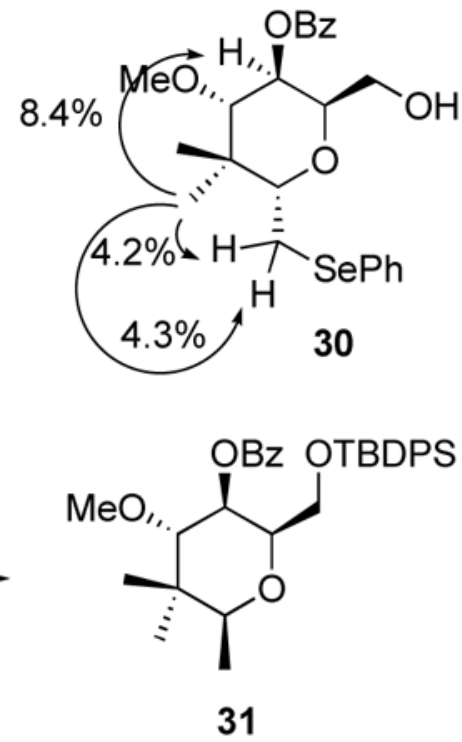

Scheme 10.

Stereochemistry Determination of 29a, and 29b 


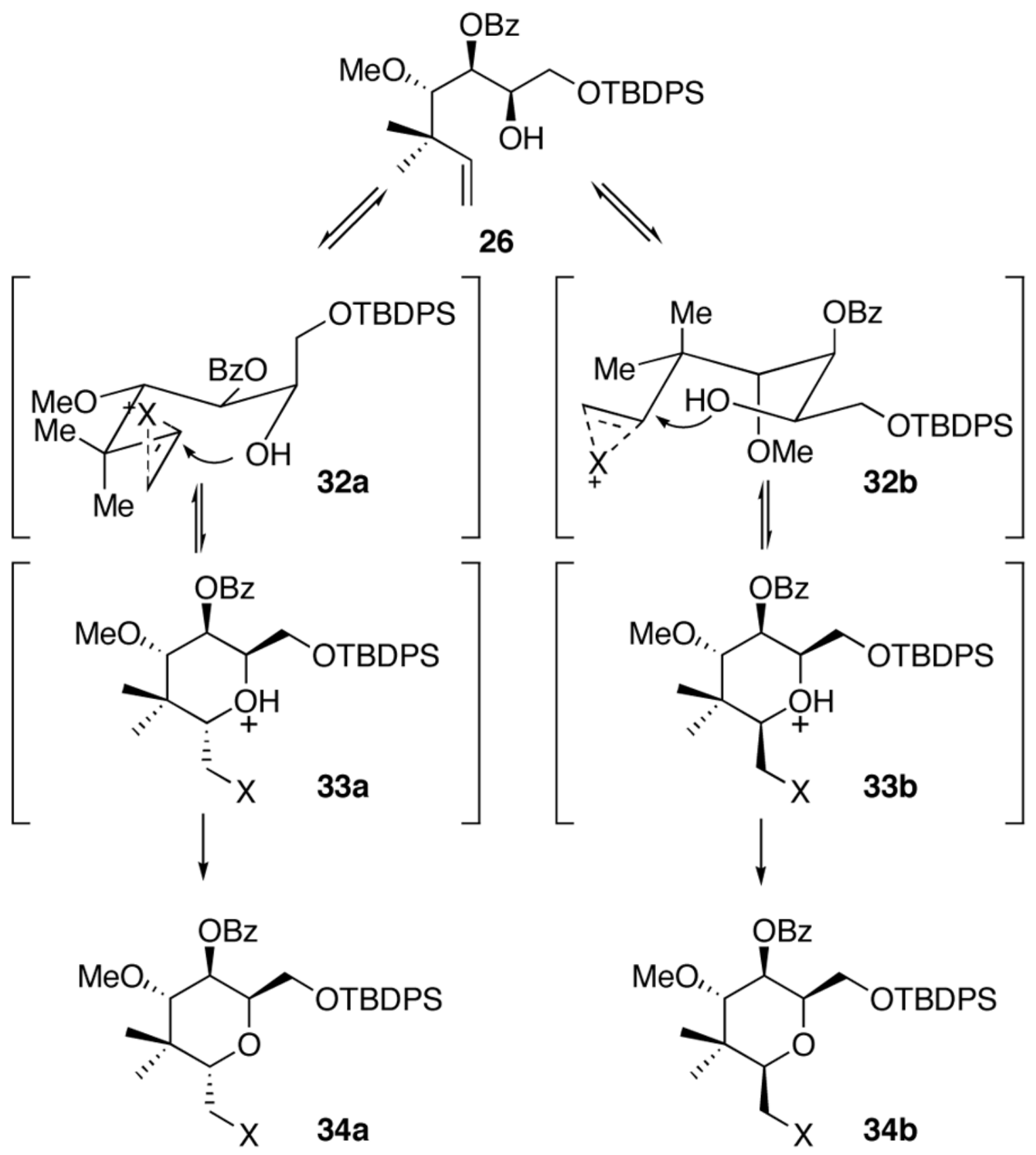

Scheme 11.

Mechanistic Pathway for Cyclization of $\mathbf{2 6}$ 


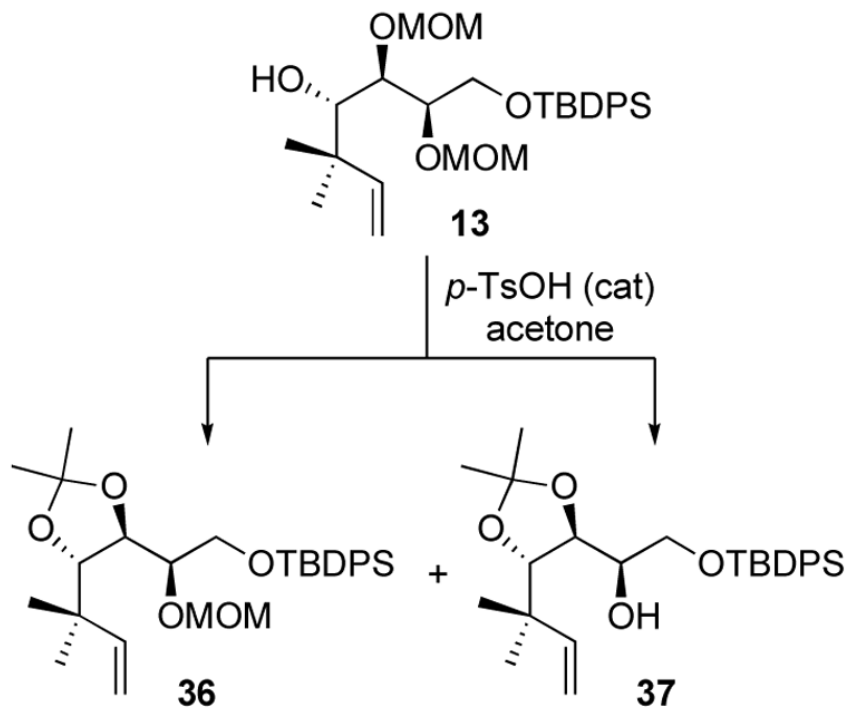

\begin{tabular}{ccr} 
rxn conditions & $\mathbf{3 6}$ & \multicolumn{1}{c}{$\mathbf{3 7}$} \\
\hline rt, 24 h & $78-85 \%$ & $6-20 \%$ \\
reflux, 36 h & $0-17 \%$ & $52-68 \%$ \\
\hline
\end{tabular}

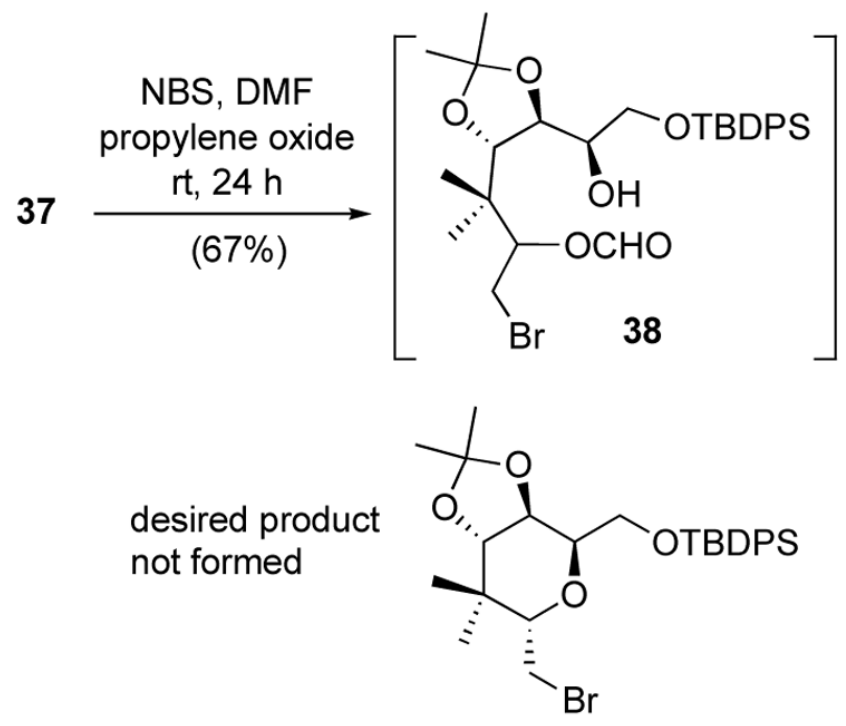

Scheme 12.

Synthesis and Attempted Cyclization of Acetonide 37 
<smiles>[R20]O[C@@H](CO)[C@@H](O[R2])[C@H](OC)C(C)(C)C=C</smiles>

25

$$
\begin{aligned}
& 39 R_{1}=B z, R_{2}=H(26 \%) \\
& 40 R_{1}=H, R_{2}=B z(46 \%)
\end{aligned}
$$

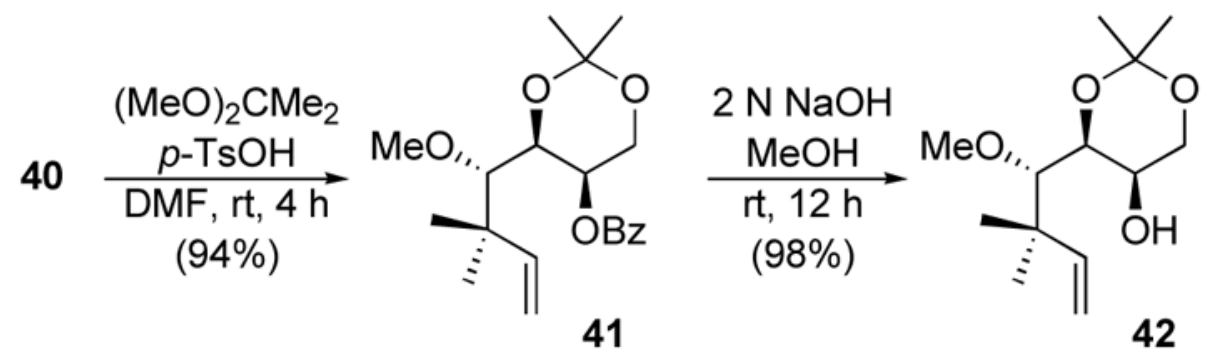

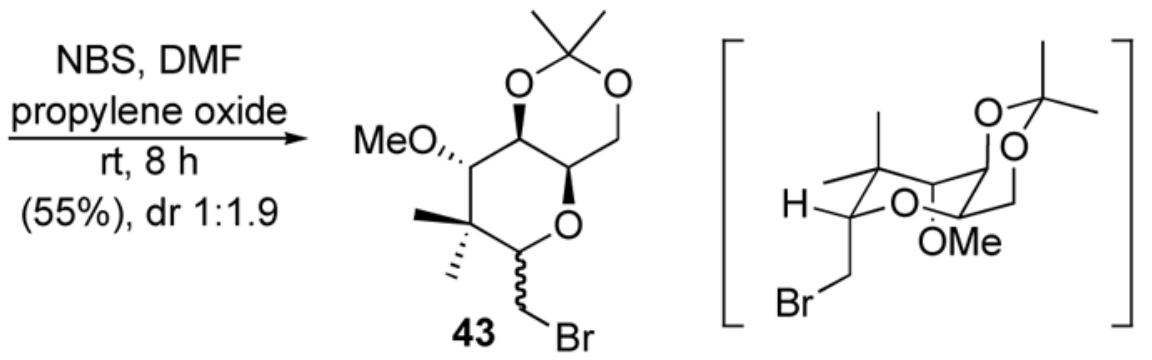

Scheme 13.

Electrophilic Cyclization of Acetonide Alcohol 42 

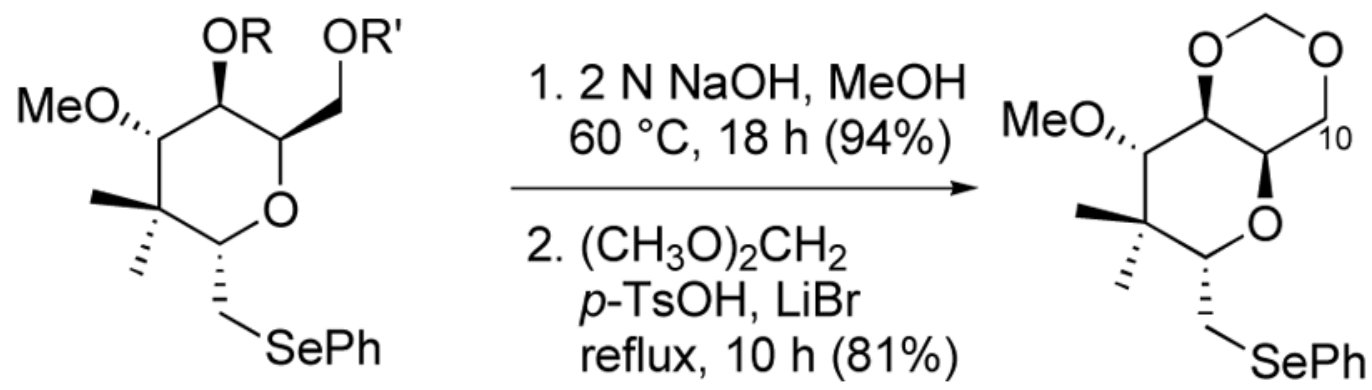

29a: $R=B z, R^{\prime}=T B D P S$

45

Scheme 14.

Construction of Dioxane Ring via Direct Methylene Ketal Formation 


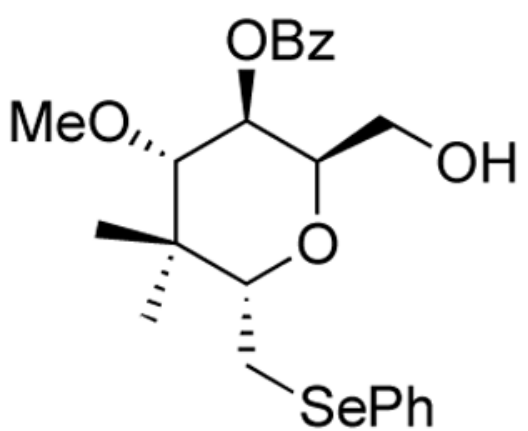

30
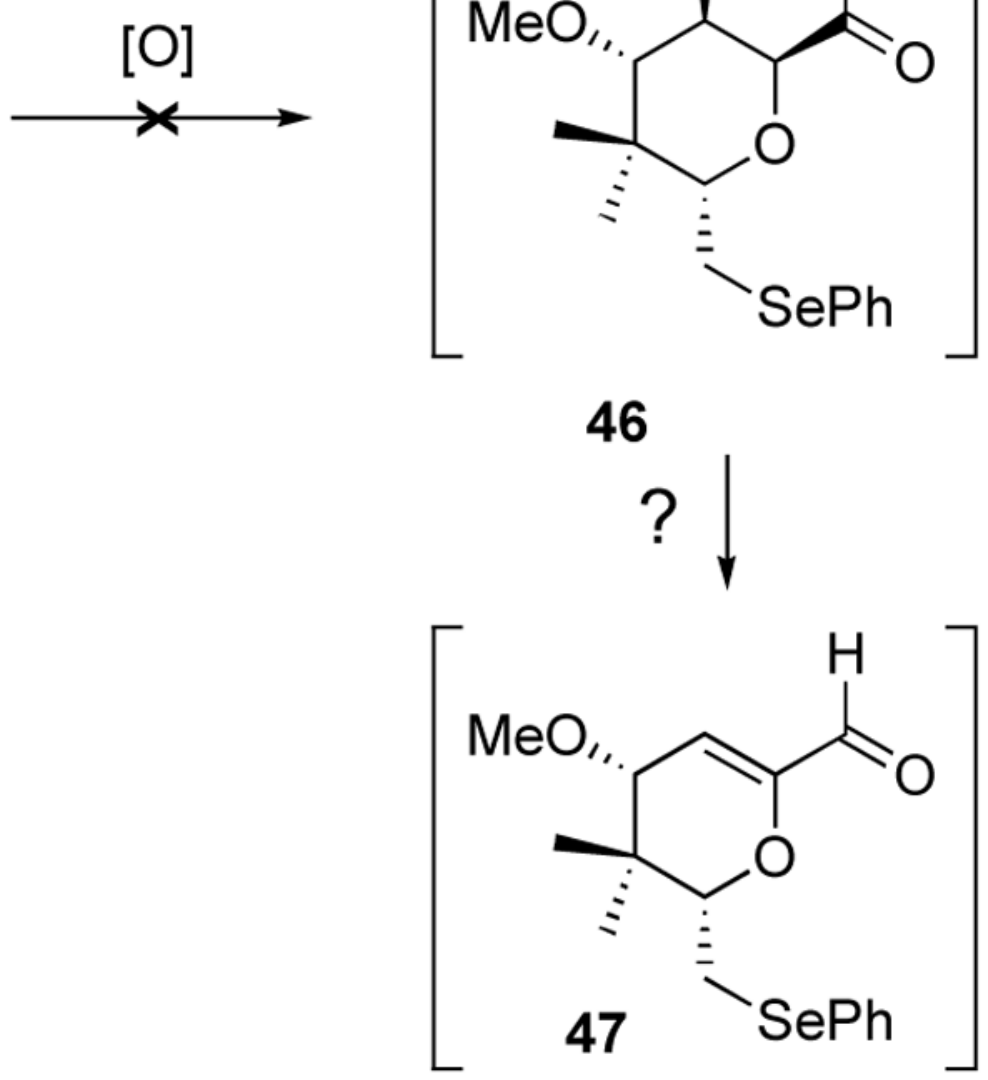

Scheme 15.

Unsuccessful Selective Oxidation of Primary Alcohol to Aldehyde 


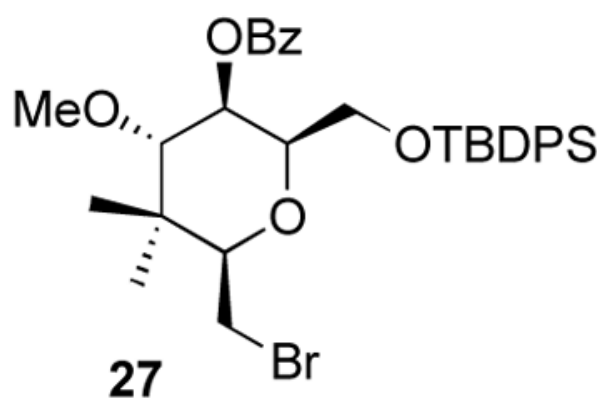

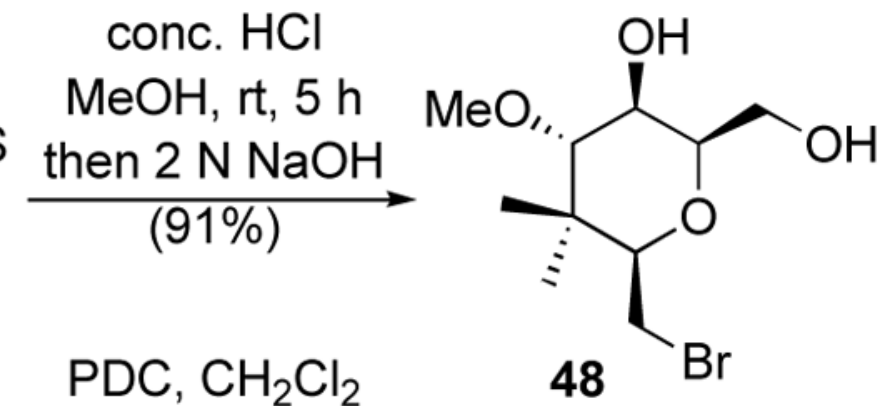<smiles>CO[C@H]1C(=O)[C@H](CO)O[C@H](CBr)C1(C)C</smiles>

rt, $24 \mathrm{~h}$
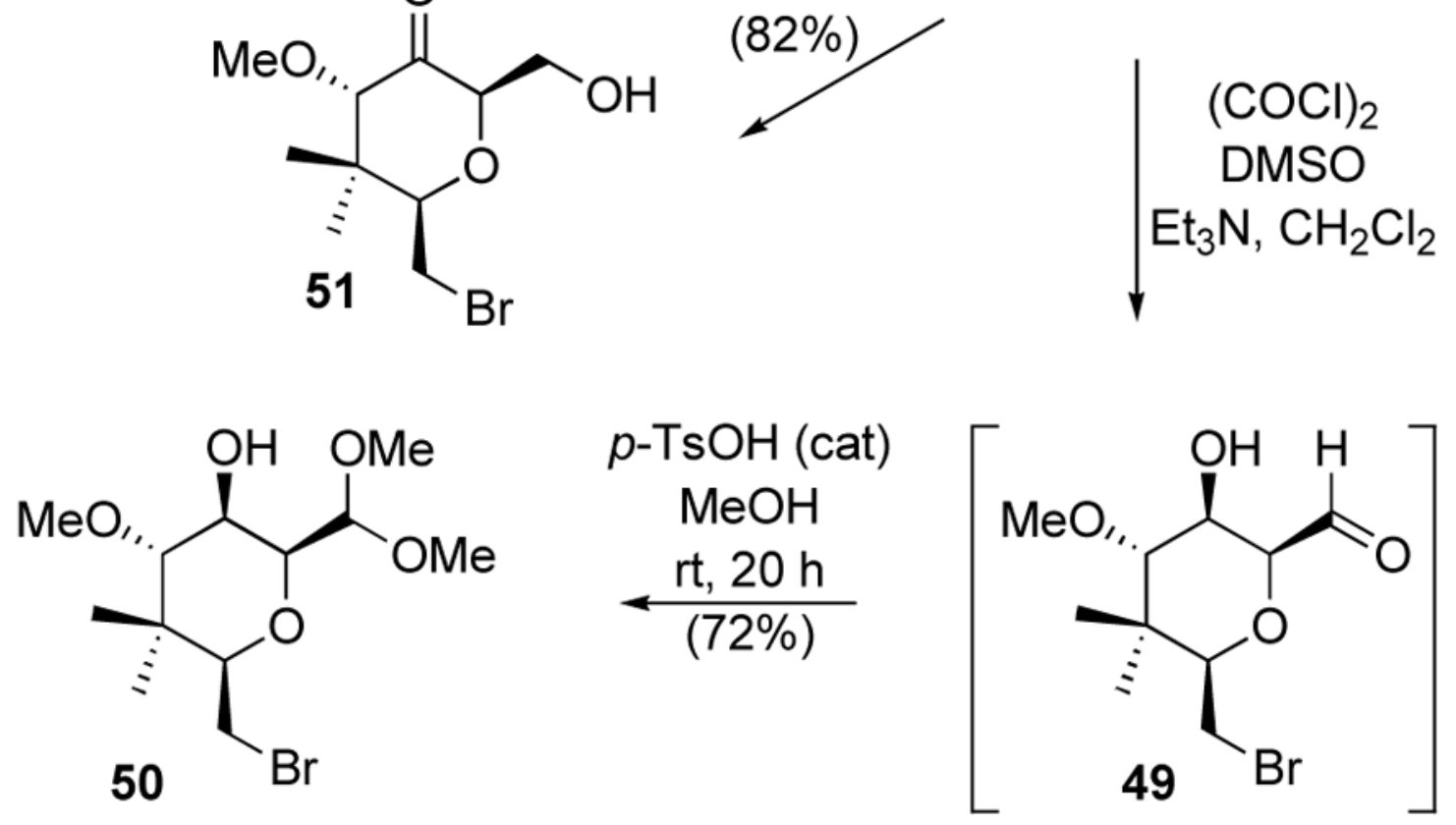

Scheme 16.

Selective Oxidations 


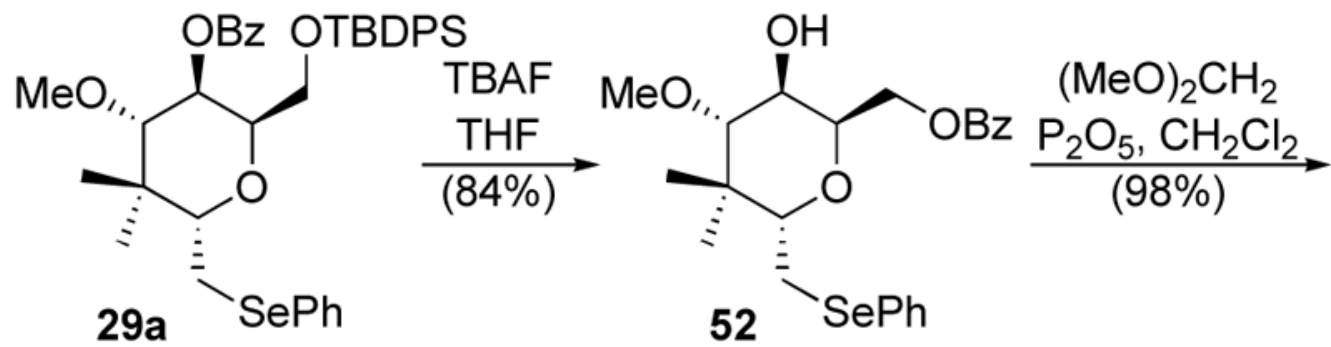

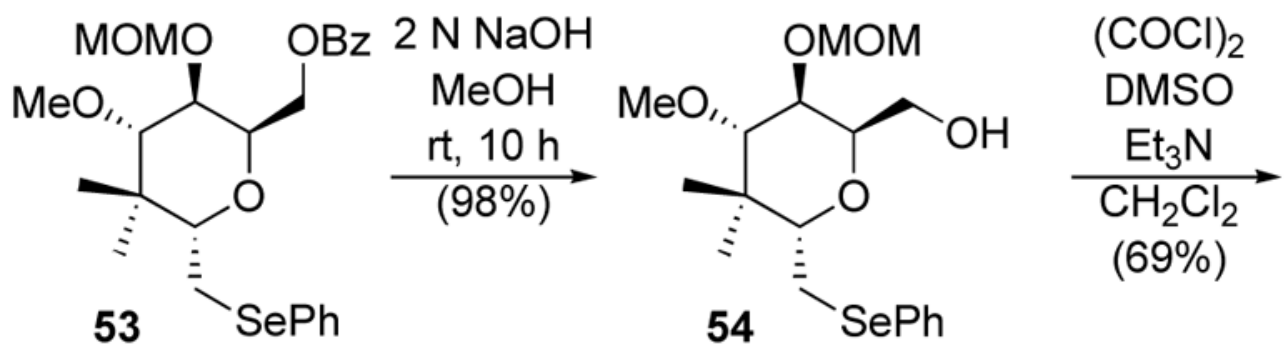<smiles>CO[C@H]1[C@@H](C=O)O[C@H](C[SeH]c2ccccc2)C(C)(C)[C@H]1OC</smiles>

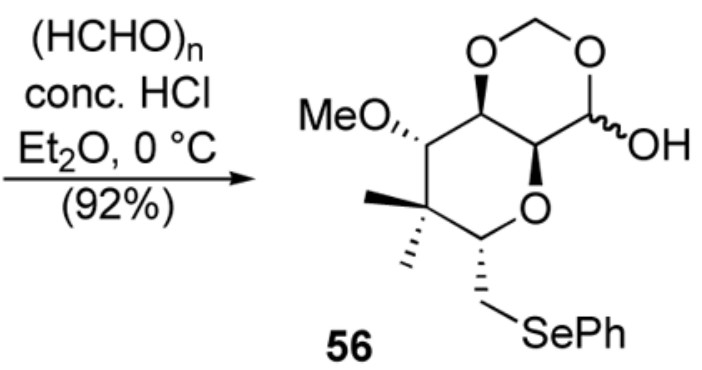

Scheme 17.

Formation of Trioxadecalin 56-the B,C-Ring System of Mycalamides 


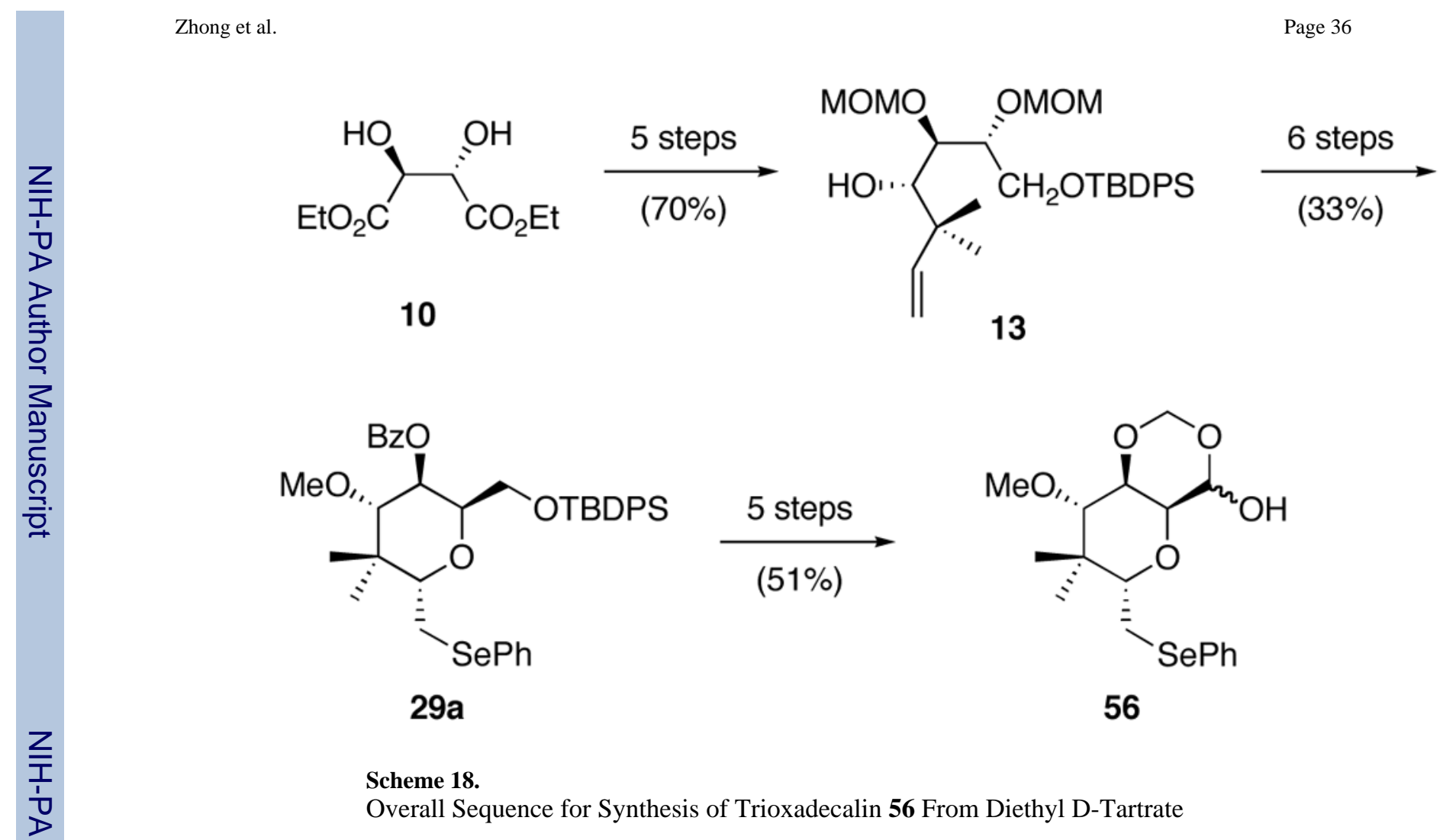


Table 1

Diastereoselective Tributylprenylstannane Addition to Aldehyde 12

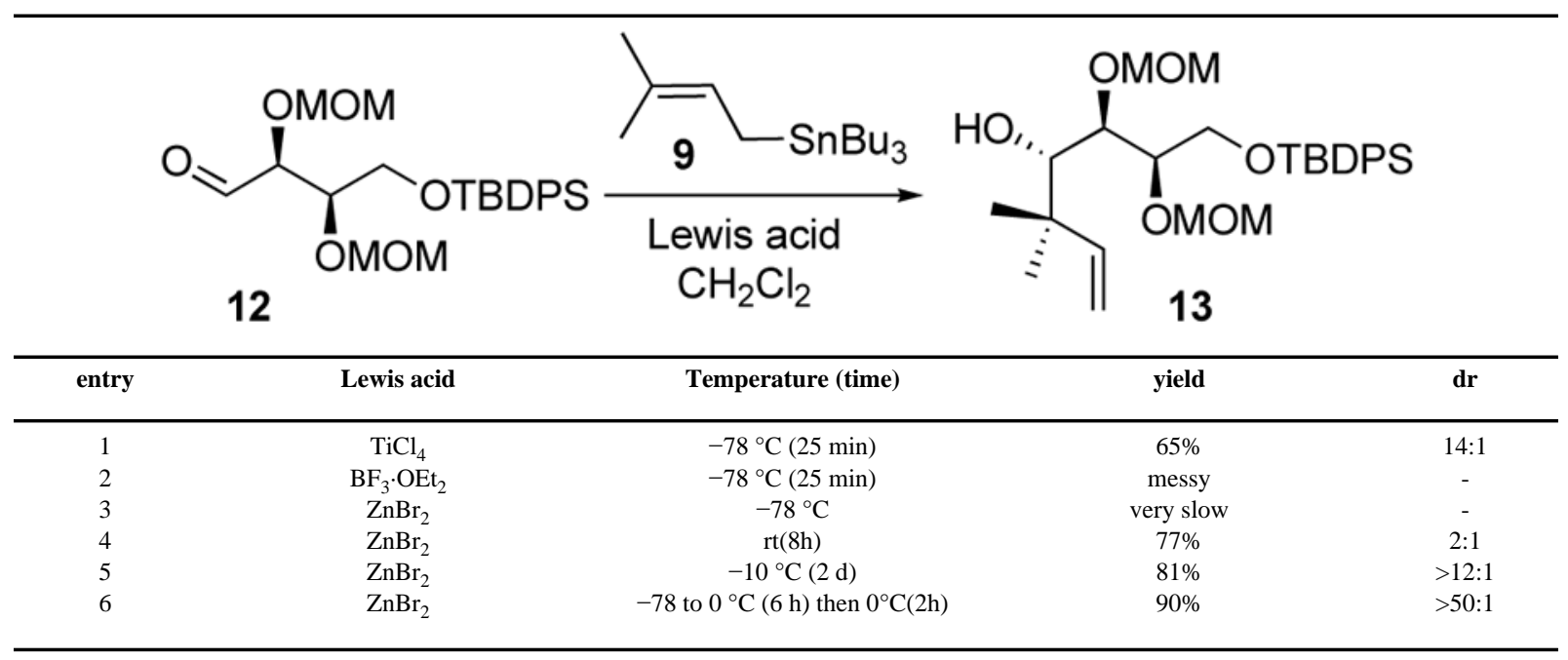




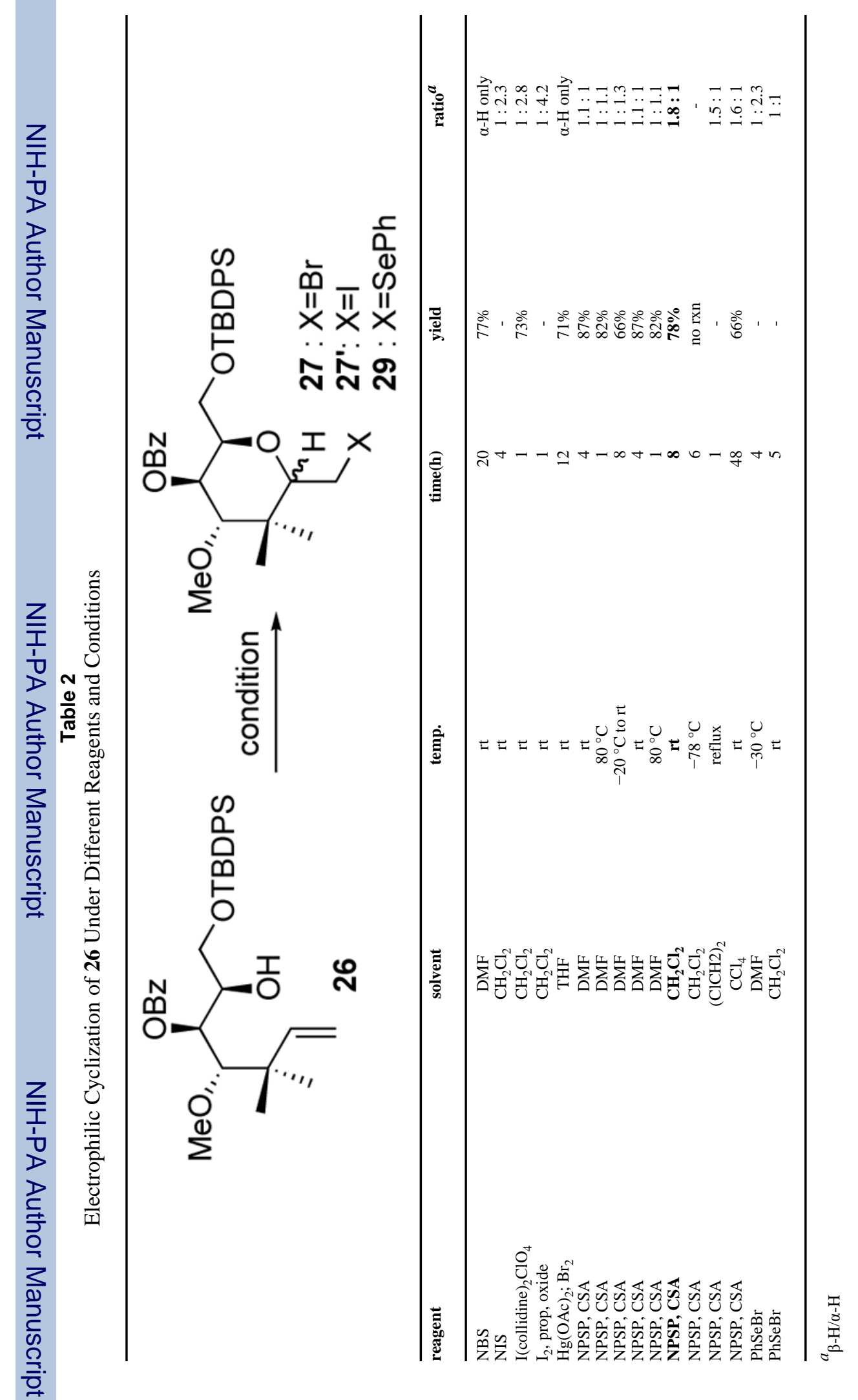

